\title{
EVALUATION REPORT
}




\section{Early Clinical Evaluation of a Robot Arm/Worktable System for Spinal-Cord-Injured Persons ${ }^{a}$}

\author{
WOODROW SEAMONE, B.A.E. \\ GERHARD SCHMEISSER, M.D.
}

The Johns Hopkins University

Applied Physics Laboratory

and

The Johns Hopkins University School of Medicine

Abstract - In Part 1, "Developmental Case Study", this evaluation traces anecdotally the increasing application of microcomputer technology in a research program examining the uses of a robot arm in the rehabilitation of the high-spinal-cord-injured person. This program, supported by the Veterans Administration since 1974, built upon still earlier VA-supported work at Johns Hopkins on powered upper-limb prostheses. The Johns Hopkins University powered shoulder prosthesis served as the basis for the Robotic Arm/Worktable System, whose evolution is described in applications ranging from handling simple reading materials to self-feeding and the operation of a personal computer, all under the user's control through the same chin control interface employed for the control of the user's power wheelchair.

Part II of this report focuses on the results of clinical evaluation in the development of the system. In the early stages of development, evaluation was provided by four subjects who used the system regularly for periods ranging from 4 months to a year. A later stage of evaluation featured a total of 16 subjects located in two VA Medical Centers, using the system for periods of from a few days to 4 months in duration.

The VA's new Rehab R\&D Evaluation Unit has begun an intensive evaluation process based upon 25 of the Robotic Arm/Worktable Systems currently on order.

\footnotetext{
This project is sponsored by the Veterans Administration Rehabilitation Research and Development Service.
}

NOTE: Mr. Seamone is a member of the Principal Staff, Fleel Systems Department. Applied Physics Laboratory, Johns Hopkins Rd., Laurel, Maryland 20707. Dr. Schmeisser is Professor of Orthopedic Surgery, The Johns Hopkins University School of Medicine, Baltimore, Maryland 21205
PART 1: DEVELOPMENTAL CASE STUDY

INTRODUCTION - Fast moving microprocessor technology leading to low-cost, highly capable microcomputer systems has been a key technical element in a research program aimed at examining the practicality of using a robot arm to assist the physically handicapped. A particu. larly critical need exists to provide the high-spinal-cordinjured person with devices that increase self-care and independence for long periods of the day. Such individuals, with total loss of upper and lower limb function, represent one of the areas of greatest need in rehabilitation engineering.

A research program at the Applied Physics Laboratory of The Johns Hopkins University has been under way since 1974, examining the applicability of robotics to the solution of this problem. The program, sponsored by the Veterans Administration, has now reached the stage of comprehensive clinical testing at Spinal Cord Injury Centers at VA Medical Centers at Richmond, Virginia, and Cleveland, Ohio.

Early in this program, visits were made to patients in Spinal Cord Injury Centers to determine the priority of needs which must be met by this equipment. Some of the important needs identified included self-feeding, management of a variety of reading materials, use of a telephone, use of a typewriter including insertion and removal of a sheet of paper, various hyglene and personal needs, and vocational capability such as the use of a personal computer.

Two approaches offer possible solutions to these needs. One approach, that of designing specific devices to address each of these needs, leads to an independent mechanical device for each of the requirements. The cost and maintenance of such devices are considerable. Operation of more than one such device in a given work area is usually difficult or impossible because of lack of integration among the mechanical designs of the subsystems. For example, a typical electromechanical magazine-reading machine is so large and bulky that it precludes placing other devices within reach of the $\mathrm{SCl}$ patient. The alternative, a single multipurpose device such as a robot, offers the promise of accomplishing many of the required tasks within a reasonable work area, and its motion flexibility should enable it to handle a variety of needed tasks.

\section{Robot Functional Requirements for the SCI Patient}

In the more severe spinal-cord-injured cases, individuals are left with little or no functional capability of the hands and arms. The basic function of the robot, therefore, is to provide a substitute for lost manipulative capabilities. Since the motions, speed, force capability, and controllability of the human arm clearly span a very wide dynamic range, compromises must be made in the selection of parameters for the robot in this human interface applicaation. Among the compromises are some related to safety. Robots in industrial applications, for example, clearly need to perform at high force levels and with brisk re- 


\section{NEW VA EVALUATION UNIT HAS PROTOTYPES ON ORDER}

You have probably already noticed, elsewhere in this issue of the Journal, a list of promising devices under evaluation by the VA's new Rehab R\&D Evaluation Unit. Third on that list is the Robotic Arm/Worktable System for quadriplegics. An order has already been placed for 25 of these in the form of production prototypes - versions of the device that have been carefully constructed so as to be suitable for commercial production in volume.

They will get intensive testing, and it is very likely that at least 100 spinal-cord-injured subjects will have the opportunity to live and work with those 25 protolypes. Obviously they will be finding some things that can or must be improved about the device. But because these prototypes will have been designed to be manufactured, it should be easier to plan improvements without the risk of creating manulacturing difficulties and delays later on.

The Robotic Arm/Worktable System has, with VA support, been under development at the
Johns Hopkins University Applied Physics Laboratory since 1974. It was in that calendar year that Woodrow Seamone and Gerhard Schmeisser and their JHU/APL colleagues first settled on the design rationale for the robotic aid that they called a "manipulator." It had grown, rather naturally, out of VA-sponsored work by the same team on externally powered upper limb prostheses, with special attention to the above-elbow amputee.

In the paper starting on these pages, principal investigators Seamone and Schmeisser provide a condensed recapitulation of the device's development with emphasis on the more recent, computer-dominated, period: they conclude with a description of a year-and-a-half of clinical field testing (starting in 1983) which preceded acceptance of the Robotic Arm/Worktable System as one of the first devices to receive the attention of the VA's new Rehab R\&D Evaluation Unit. sponsiveness, but human beings are not normally permitted within range during robot activation. In contrast, a medical application such as that considered here requires the robot to perform in intimate proximity with the user and still not present any threat to the person - even in the event of a computer fault or other system failure. Force levels of 1 or 2 pounds and maximum velocities of less than $10 \mathrm{~cm}$ per second are typical of safe values for a device operating in close proximity to a human being. And even at these safe levels, it remains important that the user or attendant be able to stop the robot easily and reliably at all times.

The range of motions should, ideally, be greater than one meter, with control precise lo within a few millimeters.

A major design consideration is whether the robot should be mounted on the user's wheelchair, or be mounted on a worktable which can be moved only by an attendant, or be made independently mobile. Early models of robots examined in the mid-70's included both wheelchair-mounted $(1,2,5)$ and worktable models $(3,4,6)$. At JHU/APL the decision was made to go to the worktable arrangement (6) because the size, bulk, and weight of a wheelchair-mounted system was judged unacceptable to the user.

The JHUIAPL project was initiated in 1974 as a follow-up on more conventional prostheticslorthotics research. The ultimate robot system cost was targeted to be less than $\$ 10,000$. At that time, no commercial robot system could be identified that had the potential performance capability to carry out the desired tasks, that was considered safe for operation in close proximity to a handicapped person, and that was within the allowable cost range. However, during the 1969-1973 time period, JHU/APL had developed a Iowcost 3-degrees-of-freedom powered prosthesis for shoulder disarticulation amputees that had the desired limited force and velocity characteristics. Since the initial study of the applicability of a robot arm was aimed at studying requirements and interface methods to control such devices (as opposed to detailed design and electromechanical implementation methods) a decision was made to use the existing JHU/APL powered shoulder pros. thesis and modify it appropriately for the early robot studies.

The basic robot arm was initially implemented with five degrees of freedom:

1. Hand grasping;

2. Wrist pronation/supination;

3. Elbow flexion/extension;

4. Shoulder motion flexion/extension (coordinated with elbow motion); and

5. Turntable motion (comparable to shoulder internall external rotation).

A sketch showing these degrees of freedom and the range of motions is shown in Figure 1. Initial testing with that model soon revealed it to be unsatisfactory, primarily because radial and vertical motions from a turntable could not carry out many of the desired functions satistactorily. The result was an early decision to add a sixth degree of freedom, implemented by mounting the robot assembly on a servocontrolled $70-\mathrm{cm}$ track. The additional degree of freedom improved the geometric capability sufficiently to allow implementation of the planned list of tasks. 


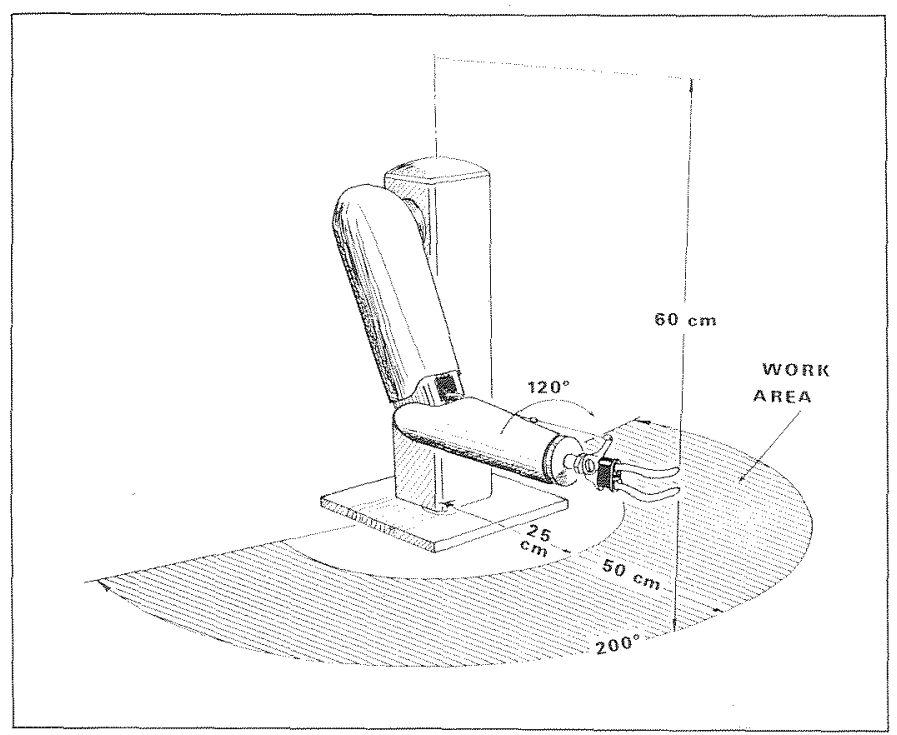

FIGURE 1

Geometry of the JHU/APL Robotic Arm.

\section{Input Modes to the Robot}

In the more severe spinal-cord-injured cases, individuals are left with little or no functional capability of the hands or upper limbs. Many of these individuals retain full range of motion of head and neck and also retain the ability to speak. Possible control inputs for mechanical devices include chin or head motion, eye tracking motion, and voice.

In early examination of control alternatives at the $A P L$, control by voice commands was considered but was rejected because it lacked high reliability. It also proved to be difficult to control the end-point motion of the robot arm by voice. (Considering the significant progress in voicerecognition technology within the past few years, it may be appropriate to reconsider the applicability of voice control to the robot problem.)

Some of the input interfaces for conventional robots considered during the early phase of this project include keyboard entry, joystick or model controls, and punched or programmed magnetic tapes. For applications to the needs of quadriplegics, most of these techniques are unsatisfactory because disabled persons lack the capability to provide inputs to keyboard and joysticks for a sustained period of time.

Chin motion input was selected, after much study and evaluation of alternatives, because of its positive control and good resolution capability. The individual user of a robot arm must be capable of watching the end-point motion of the robotic arm at all times while inputting the system. A chin motion up/down sensor with an extra degree of freedom (to permit the necessary lateral head motion) appeared to be a reasonable approach and has been implemented for all clinical evaluation in the APL robotic arm/worktable system.

\section{Integrated Robotic Arm Worktable Concept}

The JHU/APL robotic arm/worktable system has been designed with the specific goal of enabling the quadriplegic to execute total tasks with little or no altendant assistance. To accomplish this goal, a structured worktable concept is utilized; i.e., components are located on the worktable in fixed locations that allow the robot to use manual step-bystep motions or prestored computer-controlled motion trajectories to carry out a desired function. This concept makes manageable, for example, even the difficult task of putting a single sheet of paper into the typewriter.

To control the robot, the user calls up the desired program with an appropriate motion to the chin controller. The system is designed for the highly disabled person who is unable to use his arms or hands but has nearly normal range of motion of the head and neck; these motions control either the robot system or the mobility of a conventional electric wheelchair.

Steering control of the electric wheelchair is achieved by lateral motion of the chin controller (7). Torque of the motors, hence wheelchair motion, is controlled by how far the chin control lever is depressed. Reverse mode is selected by means of a microswitch button located on the chin control lever. Very little of the apparatus is in front of the user. The quadriplegic may electively push it out of the way when it is not being used.

The user drives his wheelchair with the dual-purpose chin controller for his normal daily activities. When he approaches the docking position at the worktable, a probe on the wheelchair makes an optical (infrared) connection to the worktable. The user lifts the chin controller momen. tarily and this motion serves to transfer control from the wheelchair motors to an optical link located near one arm of the wheelchair. The chin controller then modulates an infrared signal which has a pulse and a proportional mode that enable it to control the robot arm. This Iranster. ability and duality of control gives the quadriplegic muchneeded mobility (via power wheelchair) as well as the ability to drive up to his worktable and begin to manipulate the items arrayed there by means of the robot arm - and to make this transition from travel to manipulation without any need to transfer physically from the wheelchair or to deal with a change in control modality.

A block diagram of the total system is shown in Figure 2.

The robot arm is a 6-degrees-of-freedom, computercontrolled anthropomorphic limb. The individual degrees of freedom of this arm may (if the user so elects) be directly controlled by selection of the desired joint to be moved. Motion power is provided by two pancake-style DC torque motors and one geared servomotor used on the horizontal track.

One motor activates elbow flexion, wrist pronation/ supination, or shoulder flexion/extension with parallelogram motions of the forearm. The second motor, located in the vertical column, activates column rotation orterminaldevice grasping. Solenoid locks under software control lock all axes not in active motion. The controller for the arm is a microprocessor controller located within the vertical section of the arm. 


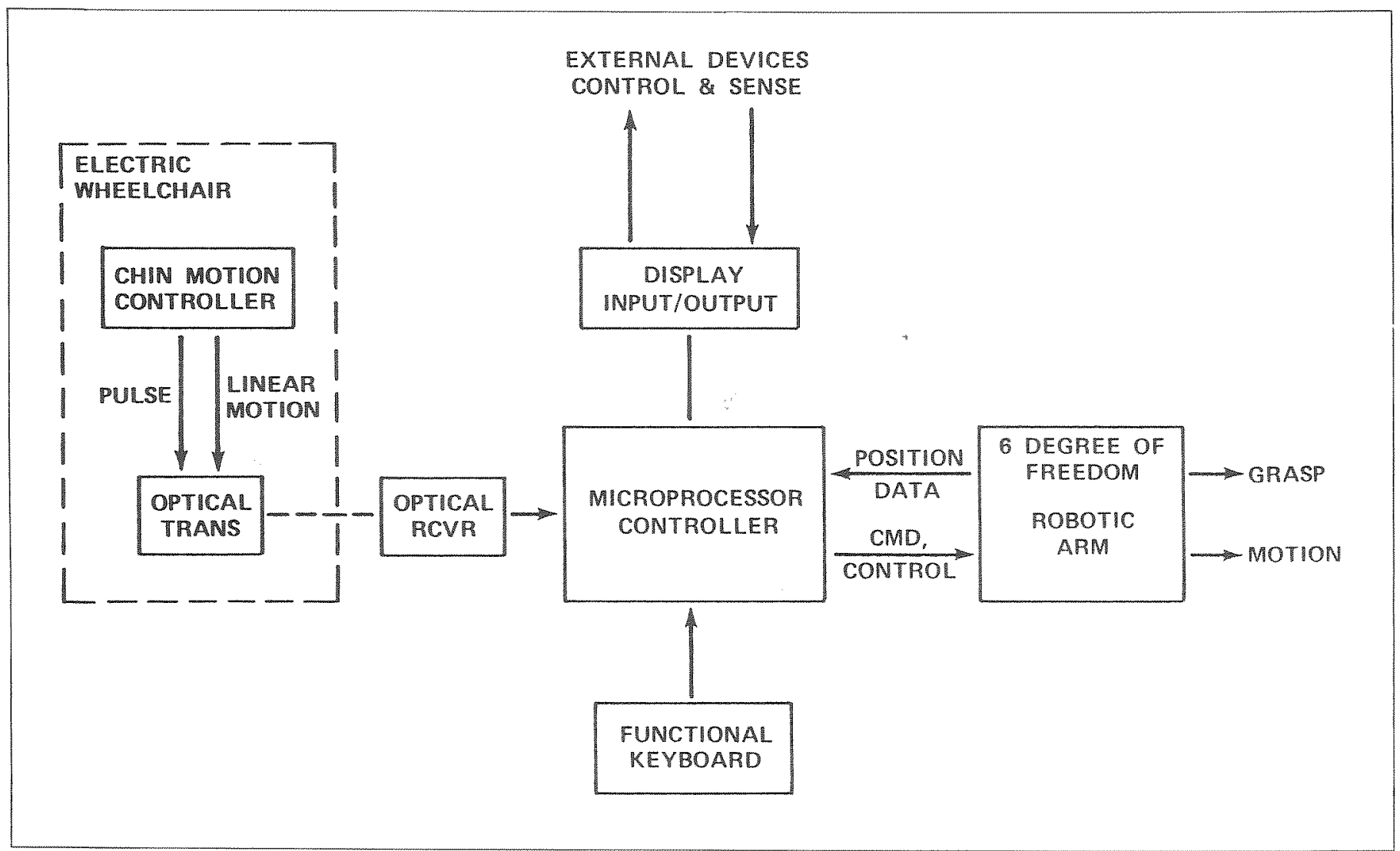

\section{FIGURE 2}

Block diagram of microprocessor-controlled robotic arm with wheelchair interface.

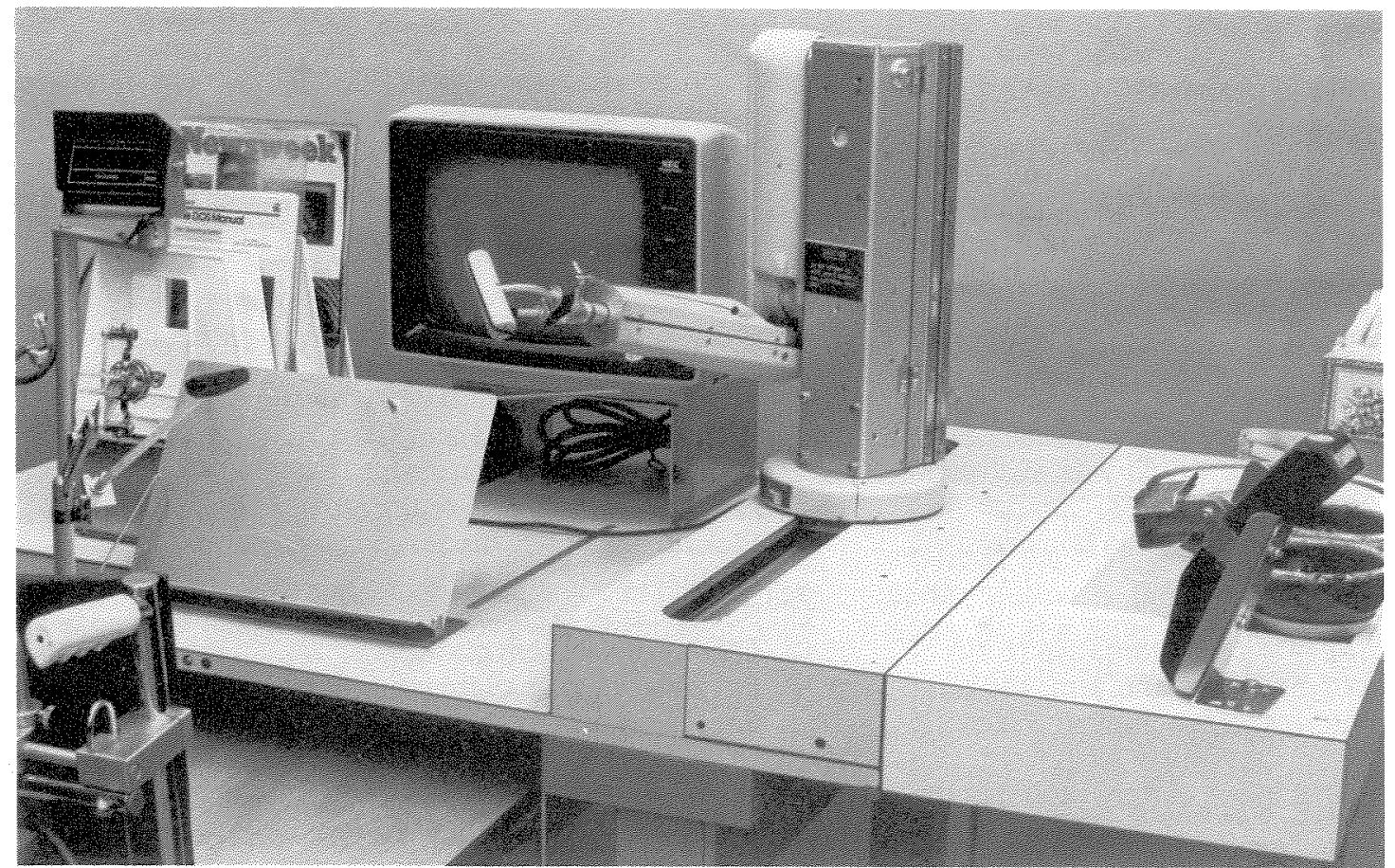

FIGURE 3

This robotic arm and worktable system is arranged for the use of a personal computer. Morse Code input device is at far left. Note telephone at far right. 


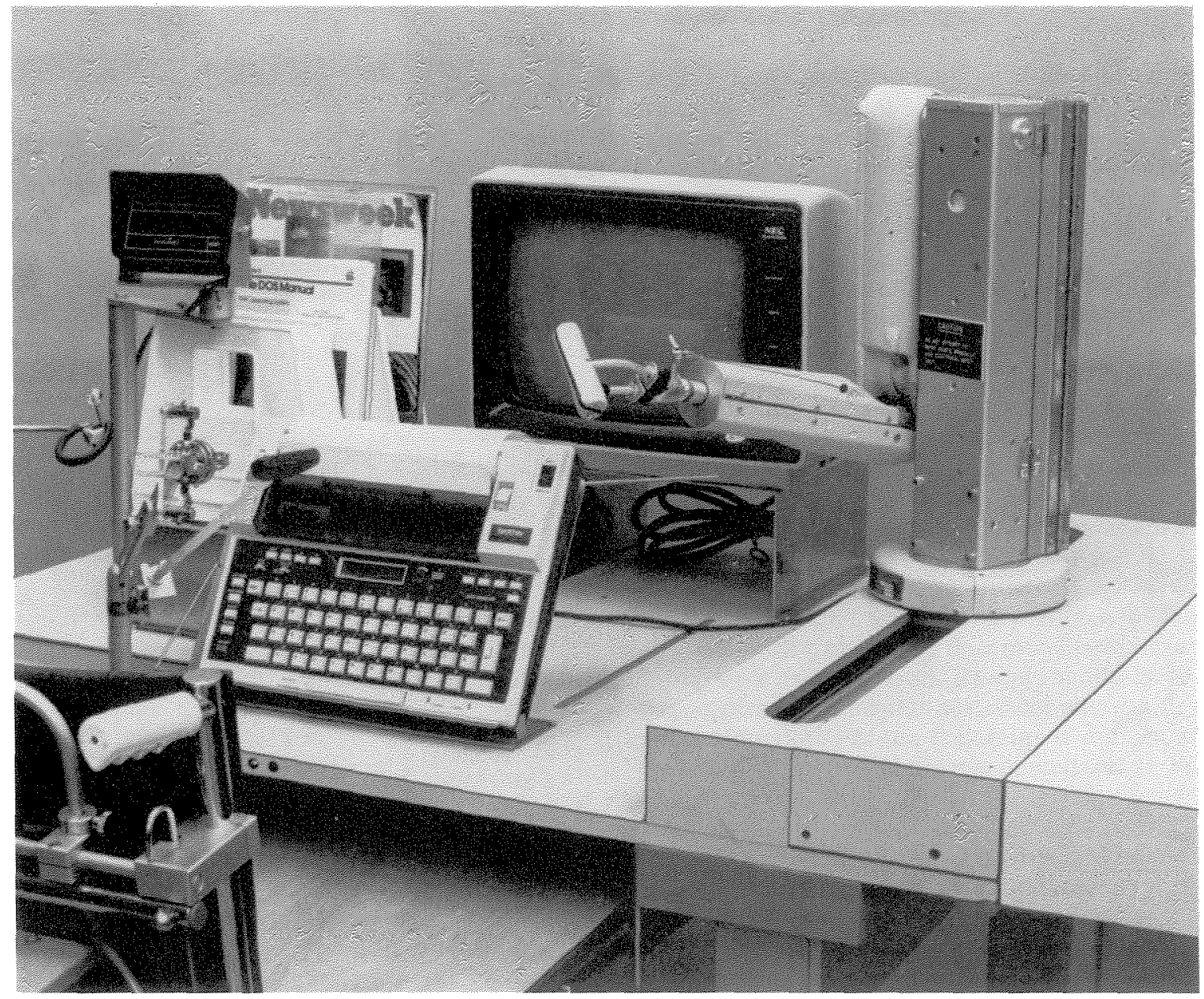

\section{FIGURE 4}

This view shows part of the worktable when configured for use of an electronic typewriter, a low-cost machine with self-correcting capability. The telephone is out of sight at the right, but within reach of the robotic arm's terminal device. Vertical post at left of typewriter carries control display at top; the loop alongside of the column is actually the chin-activated input controller for the arm. Supported by a shorter column and brackets are the Morse Code keyer and a mouthstick stored in its socket.

The worktable is configured with the robot arm on its 70-cm track, with components which are to be manipulated placed at strategic locations on the table. An example of one configuration for the worktable which was evaluated by quadriplegic users is shown in Figure 3 . Components such as a personal computer, telephone, and book reading rack are shown in that arrangement.

Prestored lask trajectories - As an alternative to direct control of any single axis-of-motion of the arm, the user may call up prestored trajectories to accomplish a specific task. The following tasks, which are only a partial list, use prestored application programs in the current model of the robot system:

1. Move mouthstick or Morse Code keyer into position;

2. Pick up telephone and place it into position for use;

3. Hang up telephone;

4. Pick up Kleenex tissue;
5. Move typewriter forward;

6. Put sheet of paper into typewriter;

7. Remove sheet from typewriter;

8. Place either of 2 diskettes into a computer disk drive;

9. Return diskettes to storage rack;

10. Pick up any of five magazines in storage rack and place on reading stand;

11. Return book to storage location;

12. Eat sandwich from plate;

13. Eat with spoon in plate; and

14. Eat from a bowl.

An important tool provided to the quadriplegic is a mouthstick which is moved into a prominent position near the front of the table by the robot. Manipulative functions, such as putting a magazine in place for reading, are accomplished by the robot, while page turning is accomplished by the occupant mouthstick. Likewise, the 
robot can bring the phone to the user's ear, but dialing telephone numbers is done with the mouthstick. The worktable may be configured in many ways with the specific vocational or personal tools desired or required by the user; another arrangement of components on the worktable is shown in Figure 4 . In addition to components such as a telephone handset, a book storage and reading rack, the table includes an electronic typewriter. This typewriter is moved into position by the robot arm, and typing is accomplished with the mouthstick. The self-correcting features of this low-cost electronic typewriter (cost is less than $\$ 200$ ) make it possible to produce error-free typed work.

The Morse Code computer interlace - Figure 3 showed the table configured to include a personal computer. The input to this computer is via Morse Code in lieu of the keyboard. A standard Morse Code keyer operated by a minute motion of the chin gives the user full control of all keyboard characters, including the Control and Shift keys. (Since the computer keyboard is not utilized directly, it can be moved to the rear of the worktable.) A series of audible dots or dashes generated by minute chin motions activates a single-chip microprocessor which translates the code into the appropriate ASCII characters and sends them to the computer. An alternate input method is to use sip-and-puff in a lube to create more characters.

These approaches were verified by tests in which quadriplegic volunteers operated an Apple computer. Speeds of 60 characters per minute are achievable, and simultaneous key entries such as those required with Control, Shift, or Repeat keys are accommodated. In demonstrations at APL, word processor programs such as Applewriter or Magic Window, and spreadsheet programs such as Visicalc, were shown to be practical software choices.

The demand for this Morse Code interface with the Apple computer was great enough to convince a manufacturer to sign a license agreement with APL to manufacture and sell the computer interface device. Integrating the computer with the robot arm gives the individual the capability to use reading materials in combination with the computer, and supports such tasks as changing disks for computer programs without the need to call an altendant.

Improvements in the self-feeding system - Self-feeding by the quadriplegic is one of the more important tasks to be evaluated with this system. During the course of the research program, the devices and the prestored programs used for self-feeding went through many design changes based on user feedback. Changes in the plate/bowl arrangement and redesign of the spoon improved the user's ability to eat sandwiches, hot dogs, French fries, and salads, as well as bite-size food. This spoon arrangement with the wire clamp is shown in Figure 5.

Two bowls and a plate may be used for eating. When the user approaches the desired portion of food or sandwich in the dinner plate with the spoon, the wire clamp is out of the way. Clamp motion is activated to grasp the food at the appropriate part of the cycle. After the sandwich or other food is brought to the mouth, the user may command the clamp to open so that he may take the last bite off the spoon.

In the prestored bowl eating program, the spoon is preprogrammed to go into the bowl (which automatically begins rotating), pick up a bite-size portion of food, scrape the bottom of the spoon to remove drippings, and proceed to the user's mouth. When eating, the user may switch among the several eating modes, e.g., from bowl to plate or from plate to bowl. The self-feeding mode was tested at APL and at the VA Medical Center in Richmond, Virginia, and shows great promise as a practical eating arrangement.

For use upon completing a meal, a prestored program is provided which directs the arm to drop the utensil and then go over to pick up a facial tissue. The user may use this tissue to clean his mouth and then drop the tissue into the wastebasket.

\section{MICROPROCESSOR CONTROLLER}

The current microprocessor-based controller uses the Mostek F8 microprocessor as the control means for the robot. (A new system utilizing a 6809 microprocessor is currently being evaluated at the Laboratory.)

A block diagram of the F8 controller and electromechanical subsystems of the arm are shown in Figure 6 . The controller resides on an $8 \mathrm{~cm} \times 36 \mathrm{~cm}$ wire wrap card on the back of the robot-arm vertical assembly. A total of 6144 words of ROM exists for controller software and up to 48 preprogrammed motion sequences: 4,017 words of batterybackup memory are available to store user-changeable motion sequences. Total power consumption is approximately three watts for the computer system.

The major tasks performed by the software are system initialization, selection and operation of arm motion under manual or preprogrammed control, and keyboard programming of new motion sequence. Under manual control, the user commands the robot arm to its desired position by issuing velocity commands by means of chin motion. Arm motion is started when the transducer is depressed halfway, the zero velocity position. The selected joint is brought to a torque balance condition and the solenoid lock associated with that joint is released. Motion of the chin lever up or down from this position produces bipolar velocity commands proportional to displacement from the zero velocity position. Visual feedback of joint motion (or observing the numerical position indicator on the display) provides the means to position the arm to a desired end point. Motion is terminated with a discrete command (a pulse on the chin controller), and a lockup of the joint occurs after velocity has been reduced by the computer to a low level.

An important mode of operation of this robotic arm is the use of preprogrammed motion sequences. Selecting operation under automatic control requires the user to select one of several tasks (phone, eat, pick up books, etc.) by calling up an appropriate page on the display panel. Page and name selection of the desired program (i.e., eat a sandwich) is achieved with proportional com- 


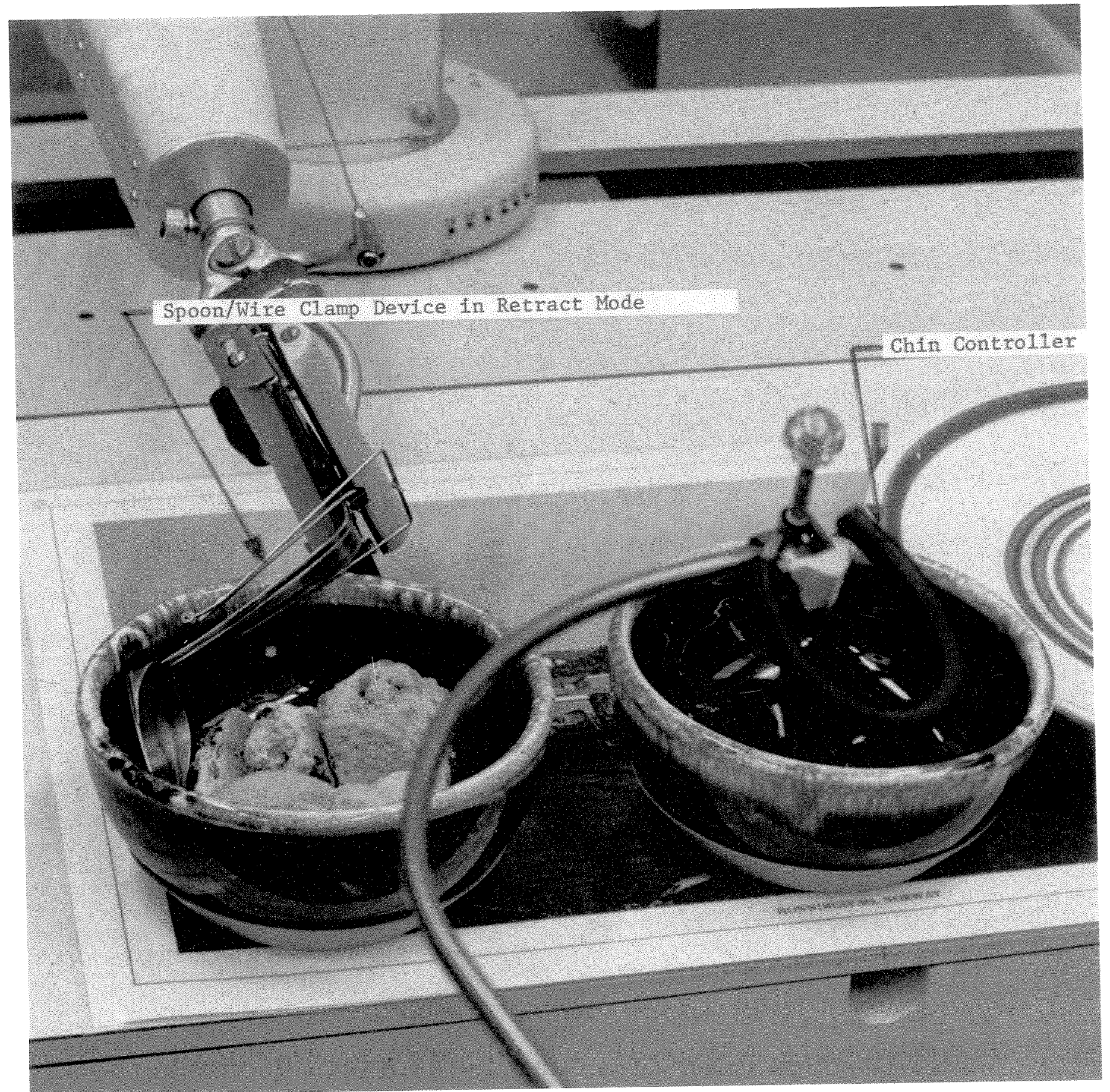

FIGURE 5

Redesigned spoon with its clamping device in retract mode. 
mand scanning the programs on each page and then selecting the desired program by a pulse command.

An interpreter program in the software interprets the selected program and then sequences the arm through the corresponding motion sequences. Motion during this phase is automatic, is acceleration-limited, and is commanded to lock up smoothly.

Should motion stall due to an obstruction, the motion being executed will time out and the next command in the sequence will be executed. The user may terminate any of the preprogrammed sequences at any time by a single pulse to the chin controller. This provides a safe stop in the event the program has gone astray.
Keyboard programming - An important feature of this system is the programming keyboard for the application programs. This keyboard is designed to be used by either the therapist or an experienced quadriplegic user.

The robot arm motions are specified by functional keys on the programming keyboard, which is shown in Figure 7 at a temporary location near the front of the table. (This keyboard is plugged into the robot arm to make program changes but is removed during normal operation.) Editing keys allow the sequential numbered commands to be easily inserted and deleted. Motion sequence files (robot arm trajectory motions) are identified by page name (collection of files) and program name (specific file). These

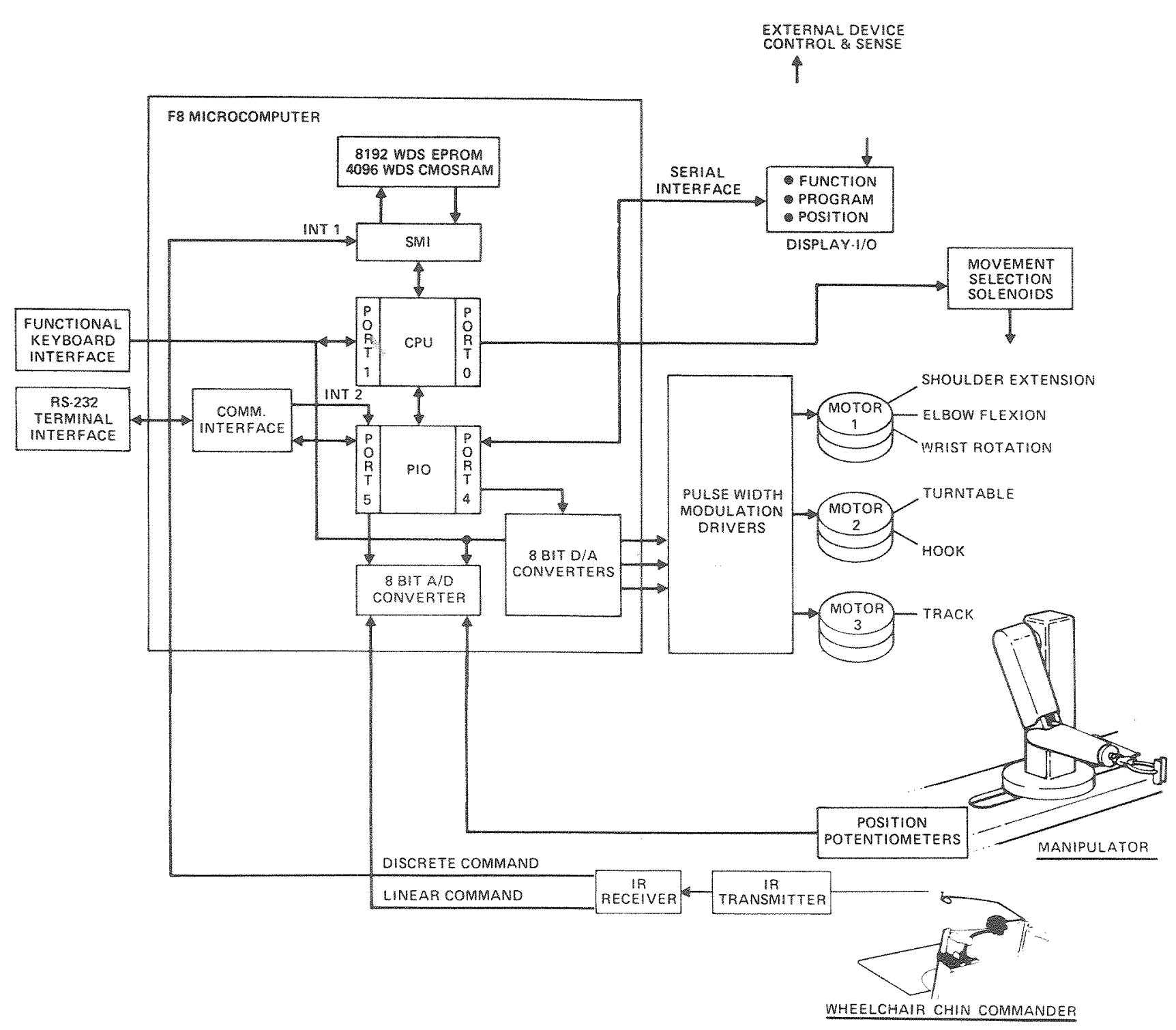

FIGURE 6

Block diagram of present microprocessor-based control system and electromechanical subsystems. 
names are specified with alphanumeric keys. All liles reside in battery-backup CMOS (complementary metaloxide semiconductor) read-write memory, and all file handling is transparent to the user.

The functional keys define BASIC-like language elements for easy specification of motion sequences. Commands exist for motion to a point, conditional and unconditional branching, stimulation and sensing of external devices, jumps to other motions sequences, pauses, and more.

FICURE 7

Partial view of worktable arranged for use of a conventional portable typewriter. Small keyboard temporarily placed to right of typewriter is used to make changes in the robotic arm's application programs; it is removed during normal operation.

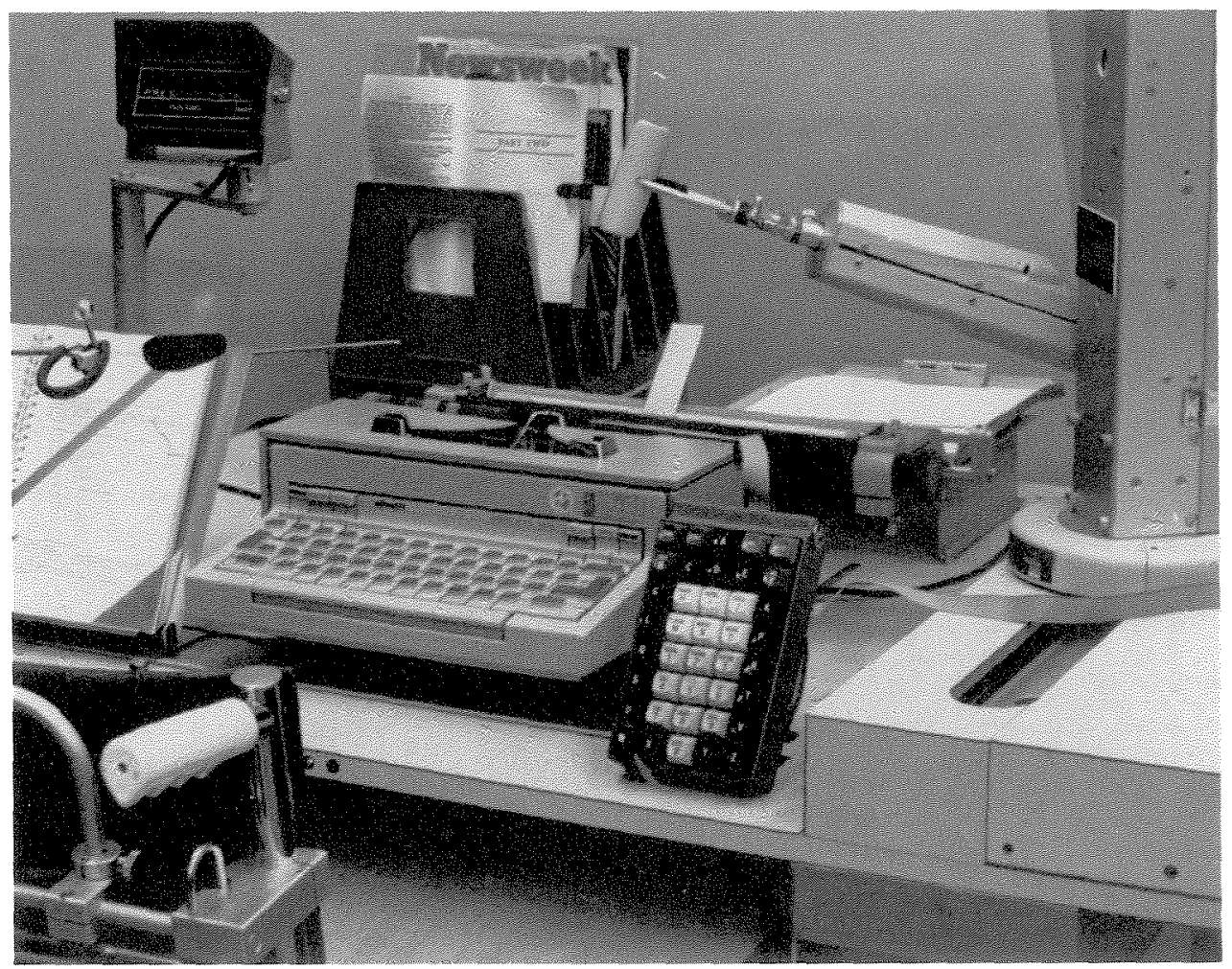

\section{PART 2: CLINICAL EVALUATION}

PHILOSOPHY - In undertaking the clinical evaluation it was presumed that some sort of Robot Arm Worktable (RAWT) system might be worthwhile for some quadriplegics to help them carry out a variety of useful manipulative tasks, as previously mentioned. It was also assumed that the APL Robot Arm Worktable (RAWT) system, as initially fabricated, would require additional development and refinement to become worthwhile for these purposes. By selecting and training quadriplegic volunteers to use this equipment and make recommendations, features needing improvement could be identified. In 1982 it was proposed to the Veterans Administration's Rehabilitation Engineering Research and Development Service ${ }^{b}$ (VA RERADS) that a 2-year clinical evaluation program be carried out at two VA Spinal Cord Injury Services. Alternate 4-month testing periods at the Spinal Cord Injury Services were to be followed by periods of approximately 2 months to upgrade the RAWT system at the JHU APL. The upgrad-

\footnotetext{
'Now incorporated in the VA's Rehabilitation Research and Develcpment Service.
}

ing was to be performed in response to the recommendations obtained from the quadriplegics during their periods of evaluation.

The ultimate objective of the clinical evaluation was to obtain information in order to bring the equipment to a level of performance that might justify commercial fabrication for general avallablity.

\section{Resources and Methodology}

Clinical evaluation of the APL RAWT and associated equipment has been conducted in three locations, and under somewhat different circumstances and with somewhat different protocols. The locations have been the Baltimore-Washington area, the Richmond VA Medical Center (RVAMC), and the Cleveland VA Medical Center (CVAMC).

Balimimore-Washington area tests-The first attempts at operation of the APL Robot Arm by quadriplegics were conducted in the Baltimore-Washington (BW) area. Clinical evaluation at this early stage of the research program was directed specifically at determining whether the Robot Arm should be attached to the user's wheelchair, a free- 
standing pedestal, a bedside table, an over-the-bed table, or a separate desk or worktable. Information was also sought on whether additional freedoms of motion were required, what sort of useful activities might the device perform, how might it be controlled most easily by the user, and what sort of ancillary work tools and their arrangement would be most useful. Informal protocols were developed for each quadriplegic as uses of the equipment were explored. The staff consisted of the authors and several interested quadriplegics selected by the authors from among those referred by miscellaneous persons famillar with the project. Two of the first four quadriplegics to use the RAWT were brought separately to the APL for initial orientation to the equipment. This was performed by demonstration and by enabling them to operate it in the laboratory for a few hours at a time under the immediate supervision of the investigators. The unit was then set up in the quadriplegic's place of residence.

For the first evaluator, BW-1, the tests were conducted at the Maryland Vocational Rehabilitation Center, a stateowned facility operated for rehabilitation of disabled persons (Table I). During his period of evaluation he was living in this institution and working with the RWAT in a well. equipped occupational therapy facility. An occupational therapist was assigned to assist him. This person had also been oriented to the equipment.

The second evaluator, BW-2, resided in a local nursing home. The RAWT was set up in his private bedroom and mounted on an over-the-bed table.
The third evaluator, BW-3, lived in his own family's suburban household. The RAWT was set up in his bedroom on a desk-lype worktable where he could operate it from his wheelchair (Fig. 8).

The fourth evaluator, $B W-4$, resided in a small state hospital for the chronically ill. The RAWT was set up on a very small table with the intention that it be used exclusively for self-feeding. For security, the unit was located in the institution's OT/PT facility. The latter three evaluators were not assigned attendants to help in the evaluation of the equipment. One of the investigators visited or communicated by phone with the evaluator approximately weekly, or as often as seemed justified.

Richmond VAMC evaluation project-Evaluation at a VA Spinal Cord Injury Service was first conducted at the RVAMC early in 1983. This evaluation followed a formal research protocol developed by the Chief of that Service and an Occupational Therapy student interested in this as a thesis project. The latter person was thoroughly oriented in the design, intended use, operation, and maintenance of the equipment in the course of a severalday visit to the JHU Applied Physics Laboratory. This person has since received her degree and has conducted the project as a full-time activity during the periods of clinical evaluation at RVAMC.

The protocol presented the aims of the project within that institution, the study design, instructional procedures, training in the operation of the equipment, patient informa-

TABLE

Summary of patient characteristics: Baltimore-Washington area

\begin{tabular}{|c|c|c|c|c|c|c|c|c|}
\hline $\begin{array}{l}\text { Quad. } \\
\text { Code } \\
\text { No. }\end{array}$ & $\begin{array}{l}\text { Age at } \\
\text { Eval. } \\
\text { (Yrs.) }\end{array}$ & $\begin{array}{l}\text { Time from } \\
\text { from Injury } \\
\text { Eval. }\end{array}$ & $\begin{array}{l}\text { Level of } \\
\text { Injury }\end{array}$ & Cause & Occupation & $\begin{array}{l}\text { Residence } \\
\text { from Injury } \\
\text { to Eval. }\end{array}$ & Physical condition & $\begin{array}{l}\text { Customary usage } \\
\text { of assistive } \\
\text { devices }\end{array}$ \\
\hline$B W-1$ & 36 & $5 y r$. & $\mathrm{CA}$ & $\begin{array}{l}\text { Water } \\
\text { skiling }\end{array}$ & Marines & VAMC & $\begin{array}{l}\text { Good trunk stability } \\
\text { Good head-neck control } \\
\text { Weak shoulder shrug } \\
\text { No upper limb function } \\
\text { No respiratory problems }\end{array}$ & $\begin{array}{l}\text { Electric wheelchair } \\
\text { with VAPC chin- } \\
\text { controller; Head- } \\
\text { stick user }\end{array}$ \\
\hline
\end{tabular}

$\begin{array}{llll}\text { BW-2 } 35 & \text { C4r. Surfing } & \begin{array}{l}\text { Ph. D. } \\ \text { physicist }\end{array} & \begin{array}{l}\text { Nursing } \\ \text { home }\end{array}\end{array}$

physicist home
Fair trunk stability Good head-neck control Fair shoulder shrug Trace of one biceps No respiratory problems
Attendant propelled wheelchair; good mouthstick user

$\begin{array}{lllll}\text { BW-3 } 27 \text { C5 } 3 y \text { Fall } \quad \text { Salesman } & \begin{array}{l}\text { His parents, Good trunk siablity } \\ \text { suburban } \\ \text { household }\end{array} & \begin{array}{l}\text { Good head-neck control } \\ \text { Weak biceps one side } \\ \text { No respiratory problems }\end{array}\end{array}$

Attendant propelled wheelchair. Marginal manual VAPC control of electric wheelchair with mobile arm supports

\begin{tabular}{|c|c|c|c|c|c|c|c|}
\hline BW-4 & 31 & 7 yr. & C5 & $\begin{array}{l}\text { Infec- } \\
\text { tion }\end{array}$ & Student & $\begin{array}{l}\text { Stale hospi- } \\
\text { tal for } \\
\text { chronic } \\
\text { diseases }\end{array}$ & $\begin{array}{l}\text { Good lrunk stablily } \\
\text { Good headmeck control } \\
\text { No upper limb lunction } \\
\text { No respiratory problems }\end{array}$ \\
\hline
\end{tabular}




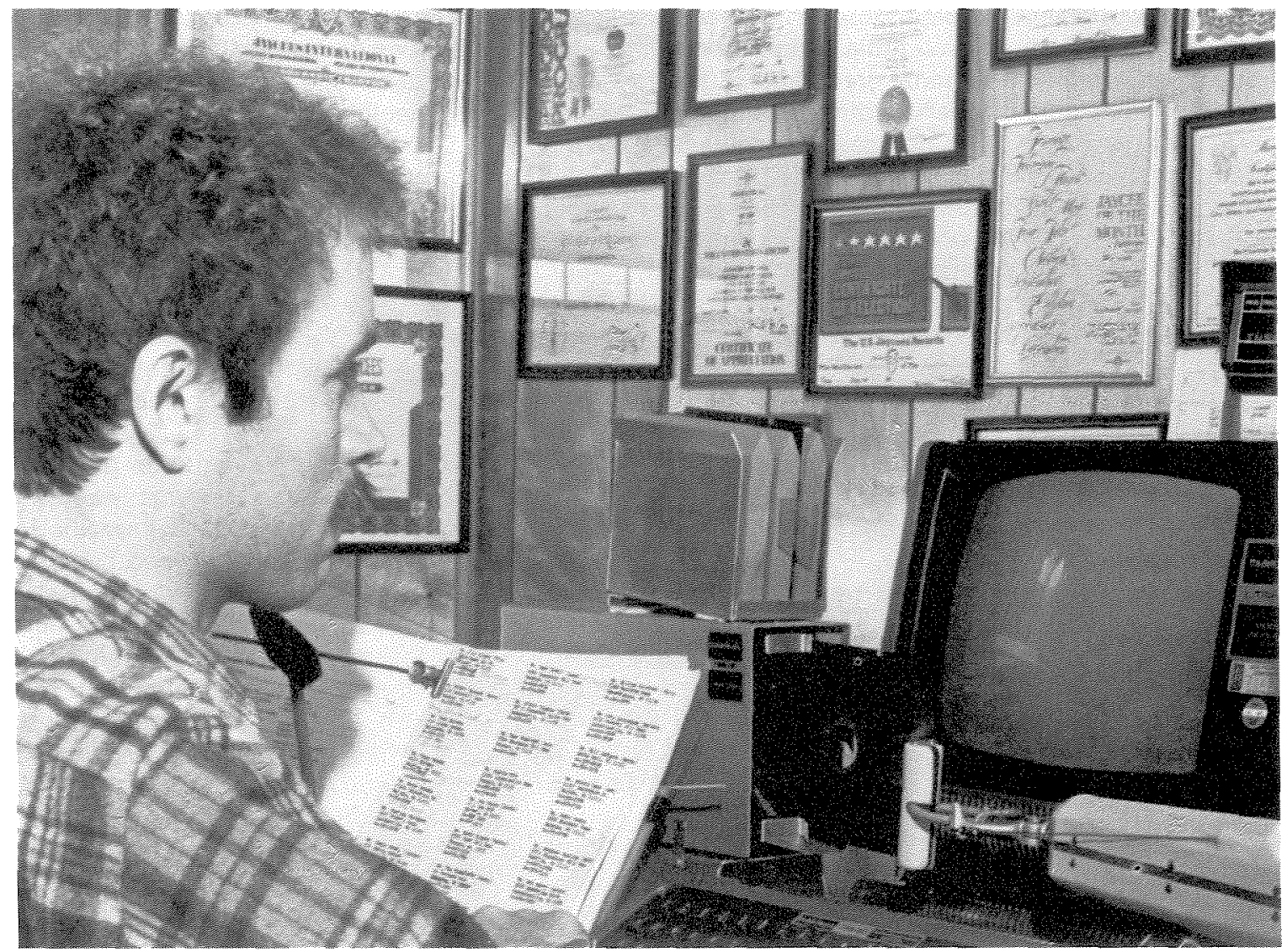

\section{FIGURE 8}

Installations of the robolic arm/worktable for evaluation in the homes and home offices of volunteer evaluators has been an aspect of the JHU/APL development program. The photo shown here appeared in the Bulletin of Prosthetics Research, BPR 10.36, Fall 1981, It shows one such volunteer: 35 -years old at the time, he is a C4-5 quadriplegic with no significant voluntary muscle power below his shoulders. In the spring and summer of 1981 he was furnished with a complete system which consisted of a dual-purpose chin-controlled wheelchair and a robotic armworktable system. For about 6 months he used the system at home, primarily concentrating on the application of the computer to his business. This user was highly enthusiastic about the wheelchair controller and he liked the worktable environment which provided multiple functions in a given work area. He did not evaluate the self-feeding capability, since he lived at home and did not feel the need for it.

tion forms, consent forms, evaluation questionnaires, etc. The projact was oriented to evaluate each of the com. ponent subsystems as well as the performance of the entire RAWT system when operated in combination with the APL Chin Controller mounted on an E\&J electric wheelchair. The quadriplegic volunteer evaluators were to be oriented in the purposes of the equipment and its opera. tion by the Principal Investigator. After learning to operate it to the extent allowed by its design and their own physical conditions, they were to evaluate it in accord with the protocol. Insofar as possible, each individual was to be scheduled to work with the equipment for at least a few hours dally over a 1 to 3 month period. This would permit two individuals to work with the equipment over the same month.

Nine quadriplegics, designated R-1 through R-9 in Table 2. were involved in the evaluation at RVAMC. All were inpatients and worked under the immediate supervision of the Principal Investigator of the project at RVAMC. Their work on the RAWT was conducted exclusively in a room adjacent to the OT facility. This room was conveniently located for wheelchair access by the participants. It was spacious enough not only to provide good approaches for a wheelchair operator to dock at the RAWT but for evaluation of wheelchair control away from the RAWT and with minimum risk to the equipment, the evaluator, or other persons.

Cleveland VAMC evaluations-Evaluation at the Spinal Cord Injury Service al CVAMC was started 6 months after the start at RVAMC. The protocol followed was similar to that at RVAMC in aims and design, but different in staff selection and evaluation procedures. For a substantial portion of the evaluation period, the Senior Occupational Therapist a CVAMC was both the Principal Investigator who developed and obtained approval of the protocol and 
TABLE 2

Summary of patient characteristics: Richmond VAMC

\begin{tabular}{llllllll}
\hline $\begin{array}{l}\text { Quad. } \\
\text { Code } \\
\text { No. }\end{array}$ & $\begin{array}{l}\text { Age at } \\
\text { (Yrs.) }\end{array}$ & $\begin{array}{l}\text { Time from } \\
\text { from Injury } \\
\text { Eval. }\end{array}$ & $\begin{array}{l}\text { Level of } \\
\text { Injury }\end{array}$ & Cause & Occupation & $\begin{array}{l}\text { Residence } \\
\text { from Injury } \\
\text { to Eval. }\end{array}$ & Physical condition \\
\hline R-1 & 25 & $8 \mathrm{mo}$ & C3 & Car & $\begin{array}{l}\text { Marines; } \\
\text { Mechanic }\end{array}$ & VAMC & $\begin{array}{l}\text { Good trunk stability } \\
\text { of assistive } \\
\text { devices }\end{array}$ \\
\hline
\end{tabular}

$\begin{array}{llll}\text { R-2 } 32 \text { Gr. Gunshot } & \begin{array}{ll}\text { Musician; } \\ \text { Horse- } \\ \text { breeder }\end{array} & \begin{array}{l}\text { Personal } \\ \text { residence } \\ \text { with wife }\end{array}\end{array}$

Poor trunk stability Fair head-neck control

Weak shoulder shrug No upper-limb runction Respirator dependent Fatigue problem

R-3 $40 \quad 8$ mo. C3 $\quad \begin{array}{ll}\text { Water } & \begin{array}{l}\text { Air Force; } \\ \text { sking }\end{array} \quad \begin{array}{l}\text { Standardiza- } \\ \text { tion Officer }\end{array}\end{array}$

Poor trunk stability

Fair head-neck control

Weak shoulder shrug

Being weaned from

respirator

Fatigue problem

\begin{tabular}{|c|c|c|c|c|c|c|c|c|}
\hline R.5 & 21 & $5 \mathrm{mo}$. & $\mathrm{C4}$ & Car & $\begin{array}{l}\text { Marines; } \\
\text { Carpenter; } \\
\text { Laborer; } \\
\text { Singer }\end{array}$ & VAMC & $\begin{array}{l}\text { Good trunk stability } \\
\text { Good shoulder shrug } \\
\text { Weak biceps one side } \\
\text { Minimal fatigue problem }\end{array}$ & $\begin{array}{l}\text { Electric wheelchair } \\
\& \text { VAPC hand- } \\
\text { controller }\end{array}$ \\
\hline R-6 & 45 & $10 \mathrm{yr}$. & $\begin{array}{l}\text { C4.5 } \\
\text { incom- } \\
\text { plete }\end{array}$ & Fall & $\begin{array}{l}\text { Inventory } \\
\text { control } \\
\text { analyst }\end{array}$ & $\begin{array}{l}\text { Personal } \\
\text { residence } \\
\text { with wife }\end{array}$ & $\begin{array}{l}\text { No hand function } \\
\text { Some limited arm } \\
\text { function } \\
\text { Somelimited ability } \\
\text { to walk }\end{array}$ & $\begin{array}{l}\text { Electric wheelchair } \\
\text { \& VAPC hand - } \\
\text { controller }\end{array}$ \\
\hline
\end{tabular}

\begin{tabular}{|c|c|c|c|c|c|c|c|c|}
\hline R.7 & 40 & $7 \mathrm{yr}$ & $\mathrm{C} 4.5$ & $\begin{array}{l}\text { Motor } \\
\text { cycle }\end{array}$ & $\begin{array}{l}\text { Senior } \\
\text { computer } \\
\text { systems } \\
\text { engineer }\end{array}$ & $\begin{array}{l}\text { Personal } \\
\text { residence } \\
\text { with family }\end{array}$ & $\begin{array}{l}\text { Good trunk stability } \\
\text { Some use of deltoids } \\
\text { and left biceps }\end{array}$ & $\begin{array}{l}\text { Electric wheelchair } \\
\text { \& VAPC hand. } \\
\text { controller }\end{array}$ \\
\hline
\end{tabular}

\begin{tabular}{|c|c|c|c|c|c|c|c|c|}
\hline R.8 & 23 & $18 \mathrm{mo}$. & $\mathrm{CA}$ & Diving & $\begin{array}{l}\text { Laborer; } \\
\text { Pipe fitter }\end{array}$ & VAMC & $\begin{array}{l}\text { Fair head-neck control } \\
\text { Poor shoulder shrug } \\
\text { No upper-limb function } \\
\text { Good fatigue tolerance }\end{array}$ & $\begin{array}{l}\text { Attendant propelled } \\
\text { wheelchair }\end{array}$ \\
\hline R-9 & 49 & $9 \mathrm{mo}$. & C3.4 & Car & $\begin{array}{l}\text { Insurance } \\
\text { salesman; } \\
\text { Textlle plant } \\
\text { manager }\end{array}$ & VAMC & $\begin{array}{l}\text { Good runk stabllity } \\
\text { Weak deltoid and biceps } \\
\text { Recently weaned from } \\
\text { respirator } \\
\text { No upper-limb function } \\
\text { Poor exercise tolerance }\end{array}$ & $\begin{array}{l}\text { Attendant propelled } \\
\text { Wheelchair }\end{array}$ \\
\hline
\end{tabular}


TABLE 3

Summary of patient characteristics: Cleveland VAMC

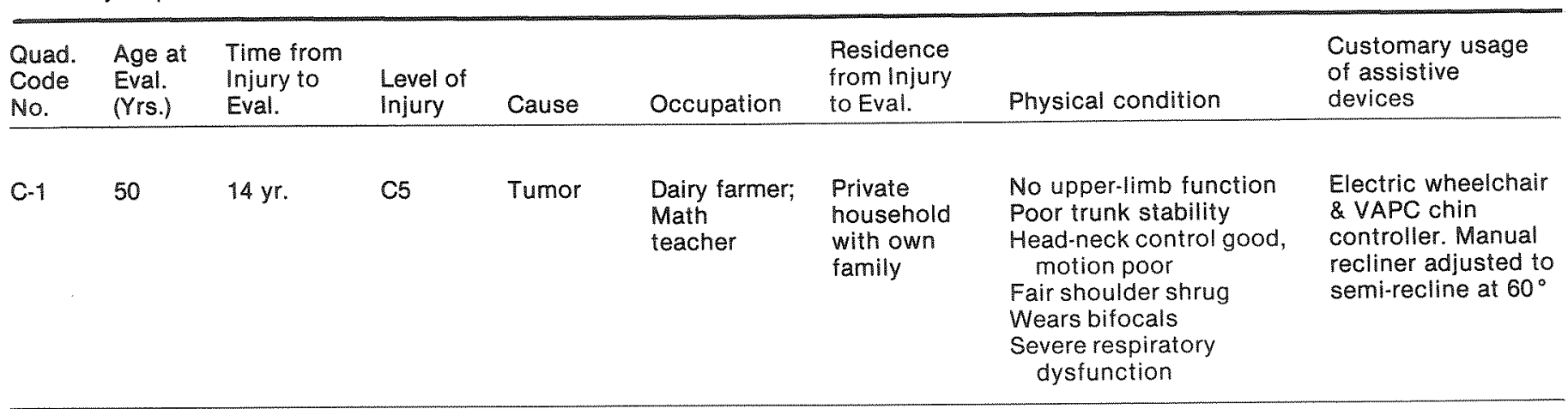

\begin{tabular}{|c|c|c|c|c|c|c|c|c|}
\hline C-2 & 56 & $26 \mathrm{yr}$. & C4 & Diving & $\begin{array}{l}\text { Military } \\
\text { serviceman }\end{array}$ & $\begin{array}{l}\text { Private } \\
\text { household } \\
\text { with own } \\
\text { family }\end{array}$ & $\begin{array}{l}\text { No upper-limb function } \\
\text { Good trunk stability } \\
\text { Head-neck control good, } \\
\text { motion poor } \\
\text { Fair shoulder shrug } \\
\text { Wears bifocals } \\
\text { No fatigue problem }\end{array}$ & $\begin{array}{l}\text { Electric wheelchair } \\
\text { \& VAPC chin } \\
\text { controller. No } \\
\text { recline. Prefers } \\
\text { headstick to } \\
\text { mouthstick }\end{array}$ \\
\hline
\end{tabular}

\begin{tabular}{|c|c|c|c|c|c|c|c|c|}
\hline C-3 & 24 & $3 \mathrm{yr}$. & $\mathrm{C} 4$ & $\begin{array}{l}\text { Injury } \\
\text { calf- } \\
\text { roping }\end{array}$ & $\begin{array}{l}\text { Military } \\
\text { serviceman }\end{array}$ & $\begin{array}{l}\text { Private } \\
\text { household } \\
\text { with own } \\
\text { attendant }\end{array}$ & $\begin{array}{l}\text { No upper-limb function } \\
\text { Poor trunk stability } \\
\text { Head-neck control good, } \\
\text { motion poor } \\
\text { Good shoulder shrug } \\
\text { All day fatigue tolerance }\end{array}$ & $\begin{array}{l}\text { Electric wheelchair } \\
\text { \& VAPC chin } \\
\text { controller. Cycles } \\
\text { power recliner fuliy } \\
\text { frequently }\end{array}$ \\
\hline
\end{tabular}

\begin{tabular}{|c|c|c|c|c|c|c|c|c|}
\hline$C-4$ & 25 & $8 \mathrm{yr}$. & $\mathrm{C} 4$ & Surfing & $\begin{array}{l}\text { Military } \\
\text { serviceman }\end{array}$ & $\begin{array}{l}\text { Private } \\
\text { household } \\
\text { with own } \\
\text { family }\end{array}$ & $\begin{array}{l}\text { No upper-limb function } \\
\text { Poor trunk stability } \\
\text { Head-neck control and } \\
\text { range good. } \\
\text { Good shoulder shrug } \\
\text { All day fatigue tolerance }\end{array}$ & $\begin{array}{l}\text { Electric wheelchair } \\
\text { \& VAPC chin } \\
\text { controller. Cycles } \\
\text { power recliner fully } \\
\text { frequently }\end{array}$ \\
\hline
\end{tabular}

\begin{tabular}{|c|c|c|c|c|c|c|c|c|}
\hline C.5 & 25 & $2 \mathrm{yr}$. & $\mathrm{C} 4$ & Diving & $\begin{array}{l}\text { Military } \\
\text { serviceman }\end{array}$ & $\begin{array}{l}\text { Private } \\
\text { househoid } \\
\text { with own } \\
\text { family }\end{array}$ & $\begin{array}{l}\text { No upper-limb function } \\
\text { Fair trunk stability } \\
\text { Head-neck control and } \\
\text { range good } \\
\text { Good shoulder shrug } \\
\text { All day fatigue tolerance }\end{array}$ & $\begin{array}{l}\text { Electric wheelchair } \\
\text { \& MED chin- } \\
\text { controller. Cycles } \\
\text { power recliner fully } \\
\text { frequently }\end{array}$ \\
\hline
\end{tabular}

\begin{tabular}{|c|c|c|c|c|c|c|c|c|}
\hline C-6 & 60 & $3 \mathrm{yr}$. & $\mathrm{C} 2$ & Fall & Salesman & $\begin{array}{l}\text { Private } \\
\text { household } \\
\text { with own } \\
\text { family }\end{array}$ & $\begin{array}{l}\text { No upper-limb function } \\
\text { Poor trunk stability } \\
\text { Head-Neck control and } \\
\text { range very poor } \\
\text { No shoulder shrug } \\
\text { Fatigue tolerance very } \\
\text { limited }\end{array}$ & $\begin{array}{l}\text { Attendant propelled } \\
\text { manual reclining } \\
\text { wheelchair always } \\
\text { partially reclined }\end{array}$ \\
\hline
\end{tabular}

\begin{tabular}{|c|c|c|c|c|c|c|c|c|}
\hline C-7 & 56 & $8 \mathrm{mo}$. & $\begin{array}{l}\text { C5 } \\
\text { incom- } \\
\text { plete }\end{array}$ & Fall & $\begin{array}{l}\text { Tree } \\
\text { surgeon }\end{array}$ & VAMC & $\begin{array}{l}\text { Central cord injury } \\
\text { Can operate hand } \\
\text { controlled electric } \\
\text { wheelchair } \\
\text { Cannot bring hand to face } \\
\text { Needs help with weight shift } \\
\text { Good trunk stability } \\
\text { Good shoulder shrug } \\
\text { Sitting tolerance } 8 \text { hours per }\end{array}$ & $\begin{array}{l}\text { Electric wheelchair } \\
\text { \& VAPC hand } \\
\text { controller } \\
\text { is } \\
\text { day. }\end{array}$ \\
\hline
\end{tabular}


also the person who was personally selecting, orienting, and providing immediate supervision of the quadriplegics working with the equipment. Because of competing obligations, a full-time commitment to this project during much of the evaluation period was not possible.

Seven quadriplegics, designated $\mathrm{C}-1$ through $\mathrm{C}-7$ in Table 3, were involved in the evaluation at CVAMC. As can be seen by the table, patients at CVAMC spent much less time in evaluation compared with Richmond quadriplegics. All were inpatients and worked under the supervision of the Co-principal Investigators at CVAMC. Their work on the RAWT was conducted in a room of a size that did not provide optimal approaches for docking a wheelchair at RAWT, but was otherwise adequate.

\section{Summary of patient characteristics}

Significant characteristics of the four quadriplegics who evaluated the equipment in the Baltimore-Washington area are summarized in Table 1. Prior to becoming quadriplegics, all were healthy adult males. They were between 27 and 31 years old at the time of evaluation and had become quadriplegics 2 to 7 years earlier. All had different occupations. Between injury and evaluation they had lived in different types of places. At the time of evaluation none had any respiratory problems, and all could sit full upright almost all day without significant fatigue. Other than their quadriplegia, all were entirely well during their evaluations. All had good head-and-neck control and range of motion. Only one, B-3, had any upper-limb function. It was significant to the extent that it enabled him to have marginal control of an electric wheelchair with a manual VAPC controller and mobile arm support, and to get some food to his mouth with the help of a mobile arm support, a special utensil secured to his braced hand, and a backstop on his plate.

Significant characteristics of the nine quadriplegics who evaluated the equipment at RVAMC are summarized in Table 2. All are male. They were between 21 and 49 years old at the lime of evaluation and had become quadriplegics between 5 months and 10 years earlier. Most lived in a VAMC from injury to evaluation. These were the ones who had become quadriplegics most recently. $\mathrm{R}-2, \mathrm{R}-3, \mathrm{~B}-4$, and R-9 had respiratory fatigue problems adequate to handicap their participation in the program. Several had head and neck control rated as only fair or poor. R-1, R-5, R-6, and R-7 had adequate hand function good enough so that they had been provided with VAPC hand controllers on their electric wheelchairs.

Significant characteristics of the seven quadriplegics who evaluated the equipment at CVAMC are summarized in Table 3. All are male. They were between 24 and 60 years old at the time of evaluation. One had become a quadriplegic 8 months earlier and had not yet left CVAMC. All others lived at home and had been injured much earlier. Although only $\mathrm{C}-1$ and $\mathrm{C}-6$ were rated as having respiratory dysfunction or a fatigue problem, C-3, C-4, and $\mathrm{C}-5$, had been provided with power recliner wheelchairs which they chose to cycle frequently. C-1, C-2, C-3, and C-6 had poor head-and-neck control or range of motion or both. Only $\mathrm{C.7}$ had been provided with a hand controller on his electric wheelchair.

\section{Site evaluation procedures and results}

The results of the evaluation in the Baltimore-Washington area are summarized in Table 4 . Since these tests were conducted during the early engineering development phase, the system being evaluated did not include many of the advanced features found in the later models. BW-1 was the first quadriplegic to evaluate the Robot Arm outside of the laboratory and for more than a few hours. Initially, the arm was mounted on a small pedestal placed immediately adjacent to his wheelchair to simulate its operation as if mounted on the wheelchair itself. It became evident that accessibility to work objects and their functional use could be achieved best if these objects were stored within reach of the arm and if the operator and these objects were always located at specific places. Robot Arm motions could then be standardized with resulting reduction of task execution time.

BW-2 was accustomed to working in his bed, dictating and telephoning technical reports based on literature arranged on a large over-the-bed reading stand. He used a simple mouthstick for turning pages in preference to a headstick or commercial page-turner. He demonstrated the feasibility of performing a variety of useful tasks including self-feeding, management of a hand-set phone for private conversations, typewriter paper loading, and moving lightweight journals individually between a reading stand and a storage file. He confirmed the advantages of mounting the Robot Arm on a motorized track on a special worktable with specific locations for the operator and the work objects. He also confirmed the need to expedite task execution by programming joint motions for performance of entire tasks. He confirmed that the table-mounted chin controller was a practical device for control of the Robot Arm. After this device was modified for electric wheelchair control and mounted on one, he tested it repeatedly, both indoors for maneuverability at slow speeds on smooth surfaces and outdoors for control at higher speeds on more irregular surfaces. He confirmed that it was a practical device for wheelchair control and was less obstructive in front of his face than a VAPC controller. (He was provided with a VAPC controller for comparison.)

BW-3 was the first quadriplegic to evaluate the Robot Arm worktable system from an electric wheelchair using a wheelchair-mounted controller with the features of independent operator docking and transmission of the control signals by infrared beam through a probe-and-socket interface. He used the system in his bedroom in his famlly's house. He found that the docking and control system and all special task subsystems worked reliably in this environ. ment; however, since the RAWT system occupied a relative large portion of his bedroom and since he had adequate residual function in his upper limbs to carry out many of the same tasks with simpler assistive devices, he con cluded that the system was not sufficiently useful to justify it for him. He recommended mounting the Robot Arm on a smaller worktable with the options of either using it ex. clusively for self-feeding or connecting it to an additional 
table in order to use the other activity devices mounted on it.

BW-4 used the small RAWT exclusively for self-feeding almost daily for several months. He ate over 100 meals with it. He stated that he enjoyed using it for this purpose, and made various recommendations for improvements in the eating utensils. He was able to compare the function of an APL chin controller with a VAPC chin controller on an E\&d electric wheelchair. His testing environments were the chronic hospital in which he resided and a local community college he attended. When operating the wheelchair he preferred the APL controller to the VAPC controller due to its reduced obstructiveness in front of his face.

The results of the evaluation at RVAMC are summarized in Table 5. At the conclusion of their evaluations four of these nine quadriplegics, R-1, R-6, R-7, and R-8, rated the RAWT, overall, very favorably. They ate 91 meals with it. They used terms such as, "Eating with it is very satisfying," "I feel liberated," "Excellent," and "I am extremely satisfied." R-7 particularly expressed the desire to have one of these units for his use at home. The responses of three other quadriplegics, R-3, R-5, and R-9, are rated as fair to good. They ate 86 meals with it. Each felt that the system was fulfilling to him in the performance of one or more tasks, but felt that the performance of other tasks should be improved. The experiences of the remaining two quadriplegics, R-2 and $R-4$, were too short for inclusion in an overall evaluation.

The two subsystems most valued by the evaluators were those for assistance in self-feeding and personal computer use. Recommendations for utensil modification and plate warming were made for improvement in self-feeding. An on-line printer was felt to be essential for fulfillment in use of the personal computer. The Robot Arm was able to insert floppy discs in the disc drive, but its performance in de. ploying literature for visual reference while the computer was in use was felt to be unsatisfactory. The designers had originally introduced telephone management into the repertoire of RAWT tasks in order to offer the quadriplegic the option of a more private conversation and one with better transmission fidelity than is possible with a speakerphone. The early evaluators at RVAMC did not think that this option was worthwhile, due to the disadvantages either of waiting for the Robot Arm to respond or of being unable to respond because of being involved in execution of another task. Modifications to expedite response were completed in time for R-6 to evaluate the equipment. The succeeding evaluators at RVAMC were either pleased or satisfied with the modified system as an improvement over a speaker-phone.

Six of the nine quadriplegics at RVAMC evaluated the APL chin controller for electric wheelchair control (Tables 2 and 5). R-1 and R-5 were VAPC hand control users. R-3 and R-4 were accustomed to VAPC chin controllers. R-2 and R-9 were accustomed to attendant-propelled wheelchairs. All six concluded that the APL chin controller was unsatisfactory due to the extent of head-and-neck control and range required, steering difficulty, starting with a jolt, poor abuse-resistance, and problems in adjustment.
The results of the evaluation at CVAMC are summarized in Table 6. At the conclusion of their evaluations none of these seven quadriplegics rated the RAWT as useful. Only two, $\mathrm{C}-1$ and $\mathrm{C}-7$, were willing to work with the RAWT for significant periods. C-1 worked with it for 78 hours over a 3 -month period and ate 25 meals with it. C-7 worked with it for 25 hours over a 5 -week period and ate 12 meals with it. He restricted his involvement with the RAWT exclusively to evaluating the self-feeding subsystem. Of the remaining evaluators, C-2 and C-3 participated for only 6 and 4 days, respectively, $\mathrm{C}-4, \mathrm{C}-5$, and $\mathrm{C}-6$ participated for only 1 or 2 days each. Experience at Richmond has indicated that adequate test time must be provided and the quadriplegic volunteer must get totally involved in order to sort out the merit of using this equipment to carry out needed tasks. This is believed to be a factor in the results from CVAMC. Problems noted included the large space required for the RAWT, poor performance reliability, poor compatibility with bifocals, food spill, poor compatibility when used with a headstick rather than a mouthstick. Recommendations by the CVAMC evaluators included increasing Robot Arm speed and lift force capabllity, expediting phone answering, refining eating utensils, and enabling more simultaneous use of subsystems, e.g., integrating telephone management with literature handling or self-feeding.

Only three of the CVAMG quadriplegics, C-1, C-2, and C-3, evaluated the APL chin controller for control of an electric wheelchair. All of these judged it as unsatisfactory. Problems cited were poor adjustability, lack of abuse resistance, starting with a jolt, excessive sensitivity, excessive head-and-neck motion required, interference with Hoyer Lift transfer equipment, lack of a power recliner on the wheelchair provided, and lack of compatibility with a reclined position.

The most frequent and significant problems for the CVAMC evaluators in using RAWT and the APL chin controller were incompatibility of the system with a reclining user, inadequacies of the APL chin controller as a wheelchair-control device, and, alternatively, lack of a commercially avallable wheelchair controller suitable for Robot Arm control as a substitute. These reasons were also percelved to be the principal causes for the limited participation of this group of quadriplegics in this project. All CVAMC evaluators except $\mathrm{C}-2$ and $\mathrm{C}-7$ were reclining users. C-7 was able to use a VAPC hand controller and declined to use the APL chin controller (Tables 3 and 6). Most of the problems identified at CVAMC have been addressed in the latest chin controller model now in test at APL.

\section{Collective experience and discussion}

Involved in this clinical evaluation in three geographical areas were 20 male quadriplegics between 21 and 60 years of age at evaluation. They ranged from 5 months to 26 years between time of injury and evaluation. Their levels of injury ranged from $\mathrm{C}-2$ to $\mathrm{C}-5$. Individual accumulations of time actually working with the equipment ranged from 1 hour to over 100 hours; 316 meals have been eaten by these individuals using the Robot Arm. 
Journal of Rehabilitation Research and Development Vol. 22 No. 11985

TABLE 4

Summary of results: Baltimore-Washington area

\begin{tabular}{|c|c|c|c|c|c|c|c|}
\hline $\begin{array}{l}\text { Quad. } \\
\text { Code } \\
\text { No. }\end{array}$ & $\begin{array}{l}\text { Duration of } \\
\text { Evaluation }\end{array}$ & $\begin{array}{l}\text { Meals } \\
\text { Eaten }\end{array}$ & $\begin{array}{l}\text { Environment } \\
\text { of Evaluation }\end{array}$ & $\begin{array}{l}\text { Equipment } \\
\text { Evaluated }\end{array}$ & Negative Aspects & Overall Impression & Recommendations \\
\hline$B W-2$ & $\begin{array}{l}1 \text { yr. } \\
3-5 \mathrm{hr} . \\
\text { /day } \\
3-4 \text { days } \\
---- \\
2 \text { mo. } \\
1-2 \mathrm{hr} . \\
/ \text { day } \\
2-3 \text { days } \\
/ \text { wk. }\end{array}$ & $\begin{array}{l}4-5 \\
\text { demo } \\
\text { meals }\end{array}$ & $\begin{array}{l}\text { Nursing } \\
\text { home }\end{array}$ & $\begin{array}{l}\text { Robot Arm on } \\
\text { over-bed table. } \\
\text { Tabletop chin- } \\
\text { controller } \\
\text { Elec. WC \& } \\
\text { APL chin- } \\
\text { controller } \\
\text { for WC }\end{array}$ & $\begin{array}{l}\text { Operation too slow } \\
\text { and ledious. Not } \\
\text { compatible with } \\
\text { operation from } \\
\text { wheelchair } \\
\text { Unable lo control } \\
\text { Robot Arm from } \\
\text { Wheelchair }\end{array}$ & $\begin{array}{l}\text { Potentially useful } \\
\text { if control effort } \\
\text { reduce and opera. } \\
\text { tion from wheelchair } \\
\text { enable } \\
\text { Okay for wheelchair } \\
\text { control }\end{array}$ & $\begin{array}{l}\text { Improve program- } \\
\text { mable mode of } \\
\text { operation. Enable } \\
\text { interaction from } \\
\text { wheelchair } \\
\text { Enable this control- } \\
\text { ler to operate Robot } \\
\text { Arm from wheelchair } \\
\text { by telemetry }\end{array}$ \\
\hline BW-3 & $6 \mathrm{mo}$. & $\begin{array}{l}4-5 \\
\text { demo } \\
\text { meals }\end{array}$ & $\begin{array}{l}\text { Family's } \\
\text { suburban } \\
\text { house }\end{array}$ & $\begin{array}{l}-\overline{-}--- \\
\text { Elec. WC \& } \\
\text { APL chin- } \\
\text { Controller for } \\
\text { WC \& Robot } \\
\text { Arm }\end{array}$ & $\begin{array}{l}\text { Large space require- } \\
\text { ments for electric } \\
\text { WC indoors }\end{array}$ & $\begin{array}{l}\text { Useful especially to } \\
\text { help with PC \& } \\
\text { phone. Prefers self- } \\
\text { feeding by orthosis } \\
\& \text { mobile arm sup- } \\
\text { port to RAWT if } \\
\text { residual function } \\
\text { permits } \\
\text { No problems with } \\
\text { APL chin-controller } \\
\text { for RAWT control } \\
\text { from WC. Enjoys } \\
\text { electric WC with } \\
\text { APL chin-controller } \\
\text { outdoors in summer }\end{array}$ & $\begin{array}{l}\text { Speed up RAWT } \\
\text { movements. Reduce } \\
\text { space requirements }\end{array}$ \\
\hline
\end{tabular}

\begin{tabular}{|c|c|c|c|c|c|c|c|}
\hline $8 W-4$ & $4 \mathrm{mo}$ & $\begin{array}{l}100 \\
\text { meals }\end{array}$ & $\begin{array}{l}\text { Chronic } \\
\text { disease } \\
\text { state } \\
\text { hospital }\end{array}$ & $\begin{array}{l}\text { Small RAWT } \\
\text { for self- } \\
\text { feeding only } \\
\text { Elec. WC \& } \\
\text { APL chin- } \\
\text { controller for } \\
\text { WC \& Robot } \\
\text { Arm }\end{array}$ & $\begin{array}{l}\text { Slow. Food fre- } \\
\text { quently falls from } \\
\text { ulensil. Food is } \\
\text { available only from } \\
\text { bowls. } \\
\text { Poor maneuverability } \\
\text { in restricted spaces }\end{array}$ & $\begin{array}{l}\text { Even with existing } \\
\text { inadequacies it en- } \\
\text { ables independent } \\
\text { self-feeding. A very } \\
\text { pleasing experience } \\
\text { for this individual. } \\
\text { The electric wheel- } \\
\text { chair with APL chin- } \\
\text { controller is a great } \\
\text { improvement over an } \\
\text { attendant-propelled } \\
\text { wheelchair and a } \\
\text { VAPC chin-controller } \\
\text { wheelchair. No ex- } \\
\text { perience with other } \\
\text { wheelchair control- } \\
\text { ler. Chin controller } \\
\text { works well with } \\
\text { RAWT. }\end{array}$ & $\begin{array}{l}\text { Improve eating } \\
\text { utensils. Enable } \\
\text { eating from a plate }\end{array}$ \\
\hline
\end{tabular}


TABLE 5

Summary of results: Richmond VAMC

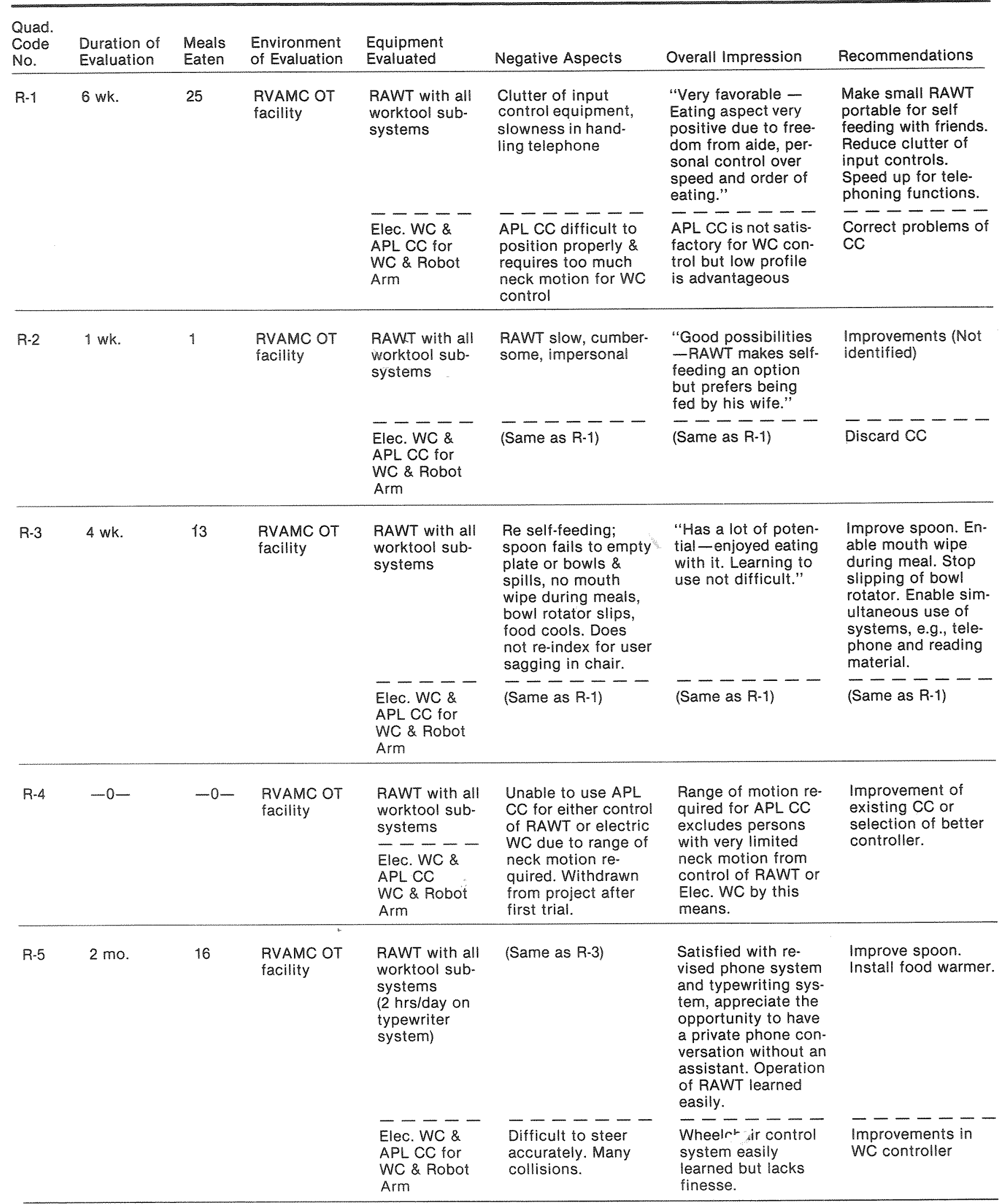


TABLE 5 (continued)

Summary of results: Richmond VAMC

\begin{tabular}{|c|c|c|c|c|c|c|c|}
\hline $\begin{array}{l}\text { Quad. } \\
\text { Code } \\
\text { No. }\end{array}$ & $\begin{array}{l}\text { Duration of } \\
\text { Evaluation }\end{array}$ & $\begin{array}{l}\text { Meals } \\
\text { Eaten }\end{array}$ & $\begin{array}{l}\text { Environment } \\
\text { of Evaluation } \\
\end{array}$ & $\begin{array}{l}\text { Equipment } \\
\text { Evaluated }\end{array}$ & Negative Aspects & Overall Impression & Recommendations \\
\hline R-6 & $5 w k$. & $\begin{array}{l}14 \\
\text { Av } 40 \\
\text { minl } \\
\text { meal }\end{array}$ & $\begin{array}{l}\text { RVAMC OT } \\
\text { facility }\end{array}$ & $\begin{array}{l}\text { RAWT with all } \\
\text { worktool sub- } \\
\text { systems }\end{array}$ & $\begin{array}{l}\text { Excessively large } \\
\text { portions of food on } \\
\text { spoon, spill, adher- } \\
\text { ence of some foods } \\
\text { to plate guard }\end{array}$ & $\begin{array}{l}\text { Expressed enthusi- } \\
\text { asm and satisfaction } \\
\text { with all RAWT func- } \\
\text { tions especially for } \\
\text { self-feeding }\end{array}$ & $\begin{array}{l}\text { Refinements in food } \\
\text { pick-up features }\end{array}$ \\
\hline R.7 & $2 \mathrm{mo}$. & $\begin{array}{l}39 \\
\text { Av } 40 \\
\text { minl } \\
\text { meal }\end{array}$ & $\begin{array}{l}\text { RVAMC OT } \\
\text { facility }\end{array}$ & $\begin{array}{l}\text { RAWT with all } \\
\text { worktool sub- } \\
\text { systems }(2-5 \\
\text { hrs/day on PC) }\end{array}$ & Food spill & $\begin{array}{l}\text { Described use of } \\
\text { RAWT as "libera- } \\
\text { tion", self-feeding as } \\
\text { "excellen"." Enjoyed } \\
\text { all features. Asked } \\
\text { to take RAWT home. }\end{array}$ & $\begin{array}{l}\text { Refinements in food } \\
\text { pick-up features. } \\
\text { Make RAWT avall. } \\
\text { able for his use al } \\
\text { home. }\end{array}$ \\
\hline $\mathrm{R}-8$ & $2 \mathrm{mo}$ & 13 & $\begin{array}{l}\text { RVAMC OT } \\
\text { facility }\end{array}$ & $\begin{array}{l}\text { RAWT with all } \\
\text { worktool sub- } \\
\text { systems }\end{array}$ & $\begin{array}{l}\text { Clutter of input con- } \\
\text { trol equipment. Low } \\
\text { telephone receiver } \\
\text { volume }\end{array}$ & $\begin{array}{l}\text { Extremely satisfied } \\
\text { with RAWT including } \\
\text { function of all sub- } \\
\text { systems }\end{array}$ & $\begin{array}{l}\text { (Same as R-7) } \\
\text { Refine input control } \\
\text { equipment to reduce } \\
\text { clutter in front of } \\
\text { face }\end{array}$ \\
\hline \multirow[t]{2}{*}{ R-9 } & $4 \mathrm{mo}$ & 57 & $\begin{array}{l}\text { RVAMC OT } \\
\text { facility }\end{array}$ & $\begin{array}{l}\text { RAWT with all } \\
\text { worktool sub- } \\
\text { systems. Input } \\
\text { by APL chin } \\
\text { controller re- } \\
\text { placed by APL } \\
\text { Bite controller. }\end{array}$ & $\begin{array}{l}\text { Unacceptable clutter } \\
\text { of control equipment } \\
\text { with APL chin con- } \\
\text { Iroller resolved with } \\
\text { Bite controller but } \\
\text { Bite controller re- } \\
\text { quires attendant } \\
\text { attachment to WC \& } \\
\text { hook up to RAWT }\end{array}$ & $\begin{array}{l}\text { (Same as R-7) } \\
\text { Especially pleased } \\
\text { with self-feeding and } \\
\text { enhancement of PC } \\
\text { usage. Bite control- } \\
\text { ler was a decisive } \\
\text { improvement in re- } \\
\text { ducing input con- } \\
\text { troller clutter. }\end{array}$ & $\begin{array}{l}\text { (Same as R-7) } \\
\text { Bite controller in } \\
\text { preference to chin } \\
\text { controller }\end{array}$ \\
\hline & & & 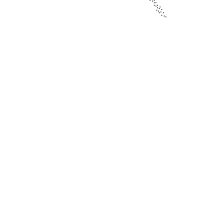 & $\begin{array}{l}\text { Elec. WC \& } \\
\text { APLCC for } \\
\text { WC \& Robot } \\
\text { Arm }\end{array}$ & $\begin{array}{l}-------- \\
\text { Chin-controller ad- } \\
\text { justments difficult } \\
\text { for attendants }\end{array}$ & $\begin{array}{l}------- \\
\text { WC control by user } \\
\text { satisfactory but ad- } \\
\text { justability and abuse } \\
\text { resistance are un- } \\
\text { satisfactory }\end{array}$ & $\begin{array}{l}-------- \\
\text { Improvements in } \\
\text { chin controller ad- } \\
\text { justability and abuse } \\
\text { resistance }\end{array}$ \\
\hline
\end{tabular}

The evaluations by the rour quadriplegics in the BaltimoreWashington area indicated that the Robot Arm would be most useful if mounted on a motorized track on a worktable with various work objects and with the operator specifically located with reference to a specific location of the arm. They confirmed that by using a manual mode of operation new tasks could be executed independently, and by using a programmed mode repetitive tasks could be executed both independently and with less effort. They confirmed that the involvement of an attendant to interface a quadriplegic in an electric wheelchair with the Robot Arm controls could be avoided by using the wheelchair controller for control input and a telemetering link to send the control signals from the chair to the arm.

Among the nine quadriplegics who lested the equipment at RVAMC, seven indicated that they found the equipment gratifying to use, especially for self-feeding. Generally, these were ones able to sit upright most of the day with little fatique and who had good head-and-neck control and range. Among the seven quadriplegics who tested the system at CVAMC, none found the system useful due to a number of problems delineated in Table 6 . Since most of these individuals did not choose to use the APL chin controller, most had interface problems with their own wheelchair controllers and recliner. Five of the CVAMC users reclined in their wheelchairs.

\section{The most trequent and significant problems were:}

1. Incompatibility of the system with a reclining user;

2. Inadequacies of the APL Robot Arm chin controller for wheelchair control; and

3. Inadequacies of any commercially avallable wheelchair controller for Robot Arm control.

There are certain considerations that need to be taken into account in solving these problems. To allow the Robot Arm to bring objects to useful locations near the user's head or food to his mouth, programs have been written with the assumption that, for the duration of the user's activity with the RAWT, his head would be vertically 
TABLE 6

Summary of results: Cleveland VAMC

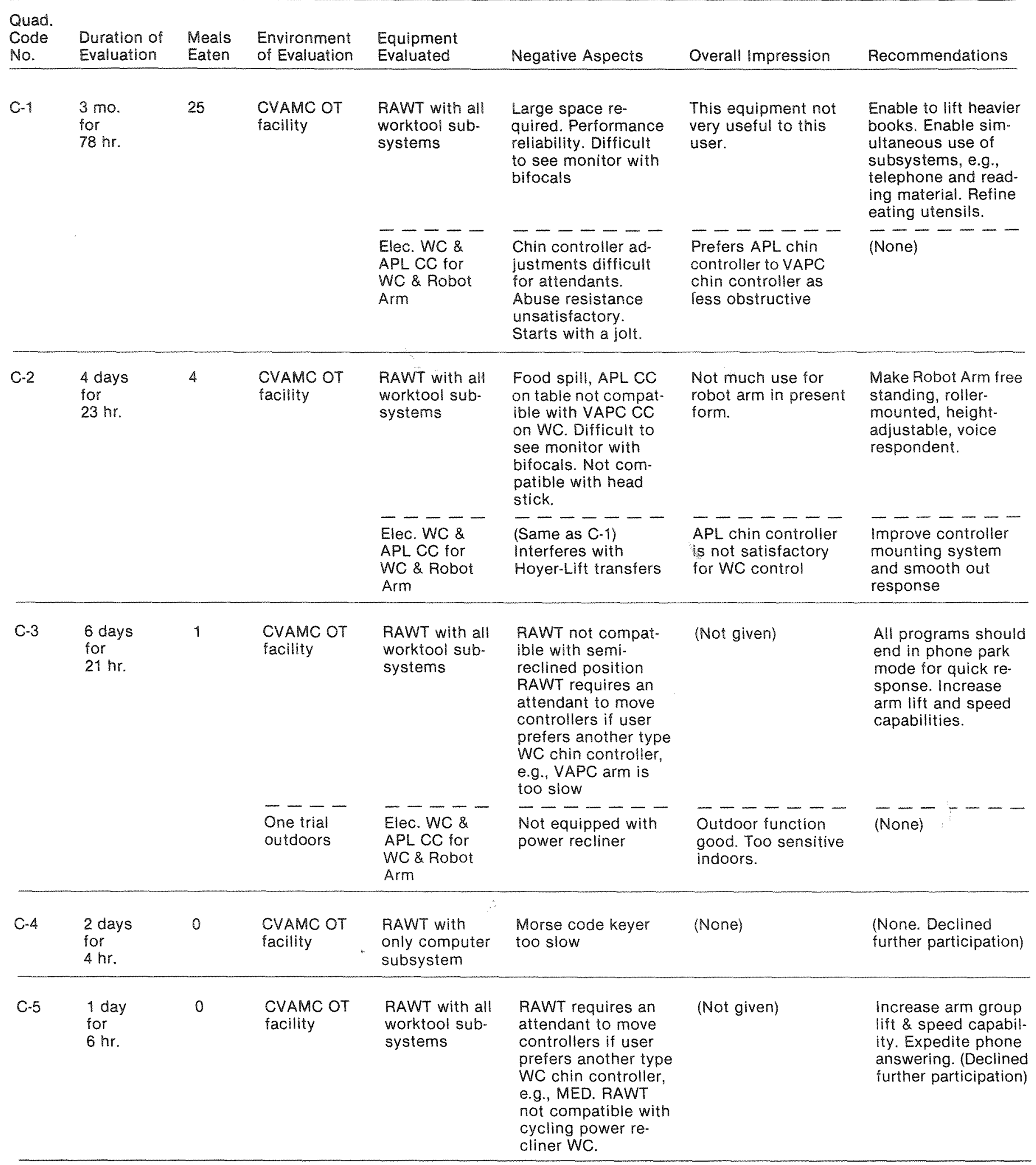


TABLE 6 (continued)

Summary of results: Cleveland VAMC

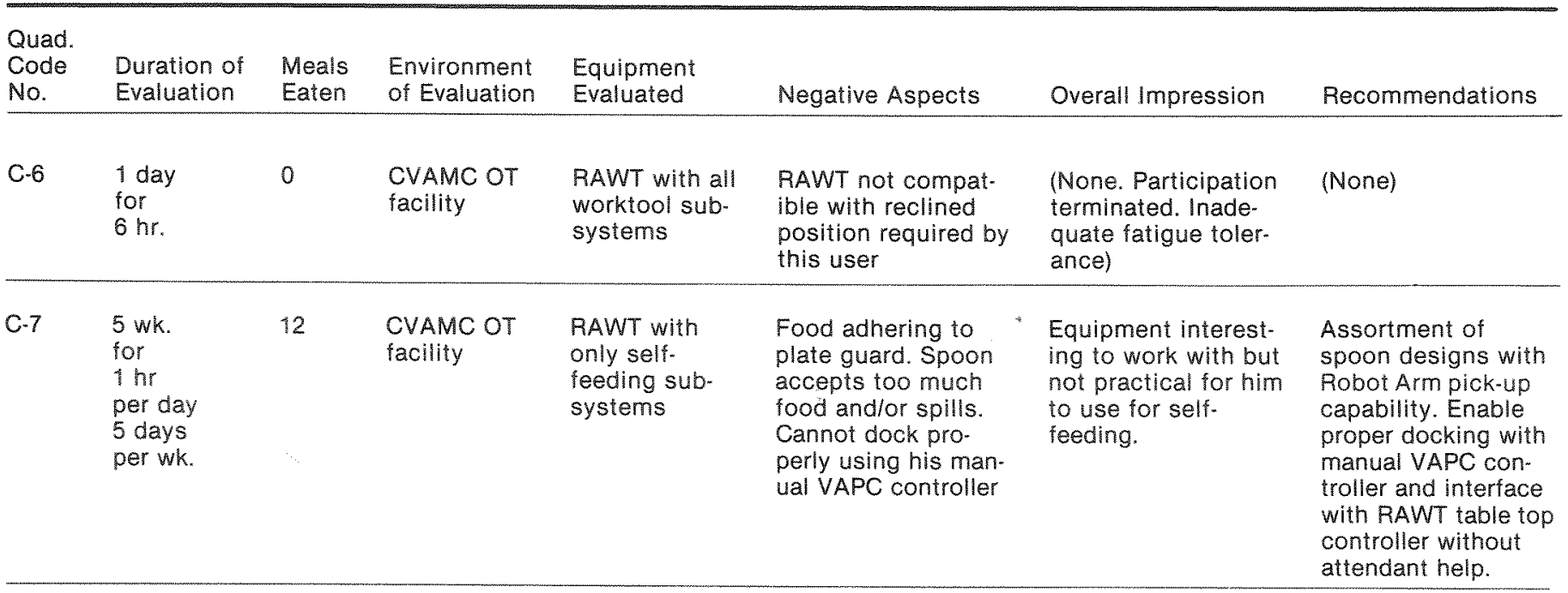

oriented, facing the table, located as close as possible to it, and within a few centimeters of a particular height above the level of the table. A recliner violates these assumptions. Modification of existing programs and reconfiguration of the docking ports can largely solve these current problems of RAWT incompatibility with a recliner.

In an attempt to work with the reclining user, one choice was to evaluate a table-mounted controller independent of the wheelchair controller. To test that approach a table mounted controller was evaluated. It could be adjusted for any given initial recliner position. Its negative aspects (adjustments, more equipment in front of the user, and the need for the help of an attendant to initially dock, to adjust the controller, and even to permit the user to leave the worktable) defeats the basic concept of independence the system is supposed to provide. Since no commercially available wheelchair chin controllers are compatible with this system, the APL chin controller was redesigned to permit it to work at various recliner positions. It has also been made substantially more abuse resistant, and more adjustable by the quadriplegic. This new controller model will undergo clinical testing early in 1985.

\section{Summary And Future Plans}

The clinical evaluation of the RAWT system over the past 2 years at the two participating VA Spinal Cord Injury Services has contributed materially to the enhancement of the system's capability. These tests have shown that the system holds promise of providing a measure of independence to certain high-spinal-cord-injured persons. Capability for self-feeding, use of a computer, and use of a telephone appeared to be its most popular features. Further clinical testing will be conducted for at least the next 18 months, to determine the extent to which modifications to address existing problems have been successful.

Some of the new engineering features include a new chin controller which addresses many of the complaints of the users, simultaneovis multiaxis motions, position com- pensation for the patient's change in posture during the day, and development of self-grooming capability. These changes, along with the basic design, are now going through the transition into a production prototype model from which a commercial manufacturer is expected to make these systems available on a broader scale to the veteran who needs and can benefit from this system

Acknowledgement - Much credit must be given to Ms. Karen Gurtler, Clinical Evaluator for the project at VA Medical Center, Richmond, Virginia, and Mrs. Carol Harley, Clinical Evaluator for the project at VA Medical Center, Cleveland, Ohio, for organizing and conducting clinical evaluation at their centers.

Active participation of the quadriplegic volunteers at these centers has been a critical contribution.

And finally, much credit goes to Mr. J.H. Loveless and Mr. W. Schneider of the Applied Physics Laboratory for their contribution to the design and implementation of the robot arm/worktable system.

References

1. Peizer $E$ and Mason CP: A Seven-Degrees-of-Freedom Telemanipulator for Tetraplegics. Proc Int'l Conf Telemanipulators for the Physically Handicapped, IRIA, Sept 4-6, 1978, pp 305-318.

2. Taylor HJ: The Development of Two Wheelchair Manipulator Systems. Ibid pp 117-131.

3. Guittet HJ et al.: The Sparticus Telethesis: Manipulator Control and Experimentation. Ibid pp 79-100.

4. Roessler $H$ et al.: The Medical Manipulator and its Adapted Environment: A System for the Rehabilitation of the Severely Handicapped. Ibid pp 63-77.

5. Bejczy AK: Jet Propulsion Laboratory Voice Command System for Motion Control. Ibid pp 103-116.

6. Schneider W, Seamone W, and Schmeisser G: AMicroprocessorControlled Arm Allows Self-Feeding for a Quadriplegic. Proc IEEE Computer Society Workshop: Application of Personal Computers for the Handicapped. Johns Hopkins University Applied Physics Laboratory. April 2-3, 1980, pp 31-36.

7. Seamone $W$ and Schmeisser G: New Control Techniques for Wheelchair Mobility. APL Technical Digest 2(3), 1981. 